Portland State University

PDXScholar

\title{
Converging Winds: Logic Hybridization in the Colorado Wind Energy Field
}

\author{
Jeffrey G. York \\ University of Colorado Boulder \\ Timothy J. Hargrave \\ Simon Fraser University \\ Desirée F. Pacheco \\ Portland State University
}

Follow this and additional works at: https://pdxscholar.library.pdx.edu/busadmin_fac

Part of the Business Administration, Management, and Operations Commons Let us know how access to this document benefits you.

\section{Citation Details}

York, Jeffrey G.; Hargrave, Timothy J.; and Pacheco, Desirée F., "Converging Winds: Logic Hybridization in the Colorado Wind Energy Field" (2016). Business Faculty Publications and Presentations. 49.

https://pdxscholar.library.pdx.edu/busadmin_fac/49

This Post-Print is brought to you for free and open access. It has been accepted for inclusion in Business Faculty Publications and Presentations by an authorized administrator of PDXScholar. Please contact us if we can make this document more accessible: pdxscholar@pdx.edu. 


\title{
Converging Winds: Logic Hybridization in the Colorado Wind Energy Field
}

\author{
JEFFREY G. YORK \\ University of Colorado at Boulder \\ UCB 419 \\ Boulder, Colorado 80309-0419 \\ (303) 807-6027 \\ jeffrey.york@colorado.edu \\ TIMOTHY J. HARGRAVE* \\ Simon Fraser University \\ 8888 University Drive, \\ Burnaby, B.C. \\ Canada. V5A 1S6 \\ Seattle University \\ (206) 816-5768 \\ timothy.j.hargrave@gmail.com \\ DESIREE F. PACHECO* \\ Portland State University \\ P.O. Box 751 \\ Portland, OR 97207-0751 \\ (303) 775-9974 \\ pacheco@pdx.edu
}

*Second and third authors contributed equally and are listed alphabetically.

\begin{abstract}
Acknowledgements: We are grateful to Tima Bansal and three anonymous reviewers for the outstanding guidance and helpful feedback they provided. We would like to thank Kathy Eisenhardt, Shon Hiatt, Suresh Kotha, Isobel O’Neil, Sarah Soderstrom, David Hekman, Tyler Wry, Stasi York, participants in the 2014 West Coast Symposium on Technology Entrepreneurship, participants in the 2013 Alliance for Research on Corporate Sustainability (ARCS) conference, and participants in a research seminar at Nottingham University Business School for their helpful comments on earlier versions of this article. In addition, we thank all of our interview participants for their time and insights. Desiree Pacheco is grateful for the support of the Center for Global Leadership in Sustainability's Faculty Development and Research Grant at the School of Business Administration, Portland State University. Jeffrey York acknowledges the financial support of the Vogt Sustainability Research fund and the Shane Faculty Scholar Gift through the Center for Education on Social Responsibility at the Leeds School of Business, University of Colorado Boulder for this research.
\end{abstract}




\title{
Converging Winds: Logic Hybridization in the Colorado Wind Energy Field
}

\author{
ABSTRACT \\ This study explores the hybridization of field-level logics, a process that integrates previously \\ incompatible logics within an organizational field. Through an inductive study of the wind \\ energy field in Colorado, we find that logic hybridization resulted when social movement \\ organizations, incumbent firms, and policy makers variously responded to incompatibility \\ between economizing and ecologizing logics. Compromise and framing efforts catalyzed social \\ movements to alter the balance of power in the field, which transformed the relationship between \\ field logics. Hybrid organizations then emerged to establish, legitimize, and embed a new set of \\ inter-linked frames, practices, and arrangements that integrated previously incompatible logics. \\ Incumbent firms and policy makers further formalized and embedded the new hybridized logic \\ in the field. Our findings suggest that the hybridization of field-level logics is a complex process \\ in which organizational actions and field-level conditions recursively influence each other over \\ time.
}




\section{Converging Winds: Logic Hybridization in the Colorado Wind Energy Field}

True, there are a few "granola technologies" such as solar power or windmills that are touted as environmentally friendly. But they are high cost and relatively unreliable.

- Denver Post editorial introducing a debate on the future of energy in Colorado (Ewegen, 1999)

What if there was an investment opportunity guaranteed to jumpstart the local economy, enhance national security, expand Colorado's energy portfolio and promote the health of the planet for future generations? It also would earn your household a 286 percent return. Would you take it?

- Denver Post editorial discussing the promise of Colorado's "New Energy Economy" (McKinnon \& Hart, 2008)

New technologies are often steeped in controversy. For example, wind energy, the production of electricity through wind turbines, has been the subject of widespread disagreement (Vasi, 2011). Environmentalists and scientists insist that wind energy can mitigate the impacts of human induced climate change through the reduction of carbon emissions (Ansari, Wijen, \& Gray, 2013; IPCC, 2013; 2014). However, many incumbent utilities, power generators, and policy makers have argued that wind energy is inefficient and expensive. These arguments encapsulate two broadly held logics that place preservation of the natural environment in conflict with economic prosperity. For example, as the quotes above illustrate, there was widespread doubt regarding the potential of wind energy in Colorado. Yet, by 2008, the state had the first voter mandated state renewable energy standard, a Governor elected on a platform of building a “clean energy economy", and over 1000 megawatts (MW) of wind energy capacity. How and why did this change occur? We explore this question through the lens of institutional logics and their role in the evolution of organizational fields. 
It is widely recognized that organizational fields are constituted by multiple, often incompatible, institutional logics (Greenwood, Raynard, Kodeih, Micelotta, \& Lounsbury, 2011; Marquis \& Lounsbury, 2007; Reay \& Hinings, 2009; Zietsma \& Lawrence, 2010). With this recognition has come growing attention to how organizations manage tensions that arise from incompatible logics within a field (Greenwood et al., 2011). Recently, hybrid organizing has been proposed as a method to manage logic incompatibility within organizations (Battilana \& Dorado, 2010; Battilana \& Lee, 2014). Hybrid organizations are seen by many as important conduits of positive social and environmental change (Battilana \& Lee, 2014; Frederick, 1995; Hoffman, Badiane, \& Haigh, 2012).

While scholars have examined hybrid organizations (Battilana \& Dorado, 2010; $\underline{\text { Pache \& }}$ $\underline{\text { Santos, 2013; }}$ Tracey, Phillips, \& Jarvis, 2011) and practices (Goodrick \& Reay, 2011; Lounsbury \& Crumley, 2007; Smets, Morris, \& Greenwood, 2012) that integrate logics at the organizational level, less is known about the hybridization of logics at the field level. Understanding the hybridization of field-level logics is critical, as this process may guide the establishment of new practices, organizations, and governance arrangements that help to resolve logic incompatibility. For example, field-level logic hybridization may help to reconcile social welfare, environmental, and economic goals (Battilana, Lee, Walker, \& Dorsey, 2012).

The purpose of this paper is to examine how logics become hybridized within an organizational field under conditions of logic incompatibility. We respond to Greenwood and colleagues' observation that although extant research has considered how organizations respond to such conditions, “... research must also address how organizational responses have feedback effects on field structure and institutional pluralism" (Greenwood et al., 2011: 357). To do so, we engaged in a historic case study of the emergence of wind energy in Colorado. As in many fields with significant environmental impacts, actors in the Colorado wind energy field faced 
incompatibility between the logics of economizing - which is associated with efficiency, profit, and private welfare - and ecologizing, which is associated with systems preservation and social welfare (Frederick, 1995; Gladwin, Kennelly, \& Krause, 1995).

Our case study and resultant model detail the complex process of field-level logic hybridization. We show that compromise and reframing by proponents of incompatible logics can unintentionally contribute to logic hybridization. By reinforcing the incompatibility of logics, compromise may motivate actors espousing subordinate logics to contest the field's powerful actors. Once field centralization is reduced, conditions are ripe for commercial entrepreneurs (in our case, wind energy firms) to develop practices and technologies that integrate elements of incompatible logics, and for new, specialized social movement organizations (SMOs) to legitimize and help embed these new practices. The end result was a hybridized field-level logic, which, building from Thornton and Ocasio (1999), we define as rules of action, interaction, and interpretation that integrate the goals of previously incompatible logics through material forms, practices, and governance arrangements. We conclude that the hybridization of logics is a process involving multiple steps that alter the structure of the field over time.

We make several contributions to the growing literature on institutional logics (e.g. Battilana \& Dorado, 2010; Battilana \& Lee, 2014; Hoffman et al., 2012; Lee \& Lounsbury, 2015; Mars \& Lounsbury, 2009; Pache \& Santos, 2013; Thornton \& Ocasio, 2008; Thornton, Ocasio, \& Lounsbury, 2012; Wry, Lounsbury, \& Jennings, 2013). First, our study unpacks the nature of logic hybridization to show how this process goes beyond "blending of diverse elements" (Thornton et al., 2012). We find that a hybridized logic does not simply aggregate elements of multiple logics, but instead integrates the goals associated with previously incompatible logics through specific material forms, practices, and arrangements that instantiate 
these goals. Second, we elucidate a process of logic hybridization at the field level. Our process model clarifies that organizational attempts to symbolically adhere to conflicting prescriptions, such as compromise (Oliver, 1991; Pache \& Santos, 2010) and framing (Lounsbury, Ventresca, \& Hirsch, 2003; Snow \& Benford, 1988) may not resolve logic conflict, but rather trigger further field-level change. Within this process we find that logic hybridization is dependent upon prior developmental changes in the relationship between incompatible logics. In our case, the assimilation of the means of one logic into the goals of another was an important step towards hybridization. Third, we illuminate the critical role of new hybrid organizations in embodying and legitimizing the hybridization of conflicting logics at the field level.

\section{THEORETICAL BACKGROUND}

Institutional logics are socially constructed "rules of action, interaction, and interpretation that guide and constrain" individuals and organizations within an organizational field (Thornton \& Ocasio, 1999: 804). Logics are comprised of both symbolic elements such as shared beliefs, interests, preferences, and goals, and material means such as practices, governance arrangements, and organizational forms (Thornton \& Ocasio 2008; Thornton et al, 2012). For example, Thornton (2004) shows that the once-dominant editorial logic in higher education publishing specified symbolic elements including goals (e.g., to build the publishing house's prestige) and the material means of accomplishing these goals, such as authority structures (e.g., ownership by a powerful founder-editor).

Logics influence actors' behaviors within organizational fields, which are "relational spaces ... where disparate organizations involve themselves with one another" to collaborate on, or contest, issues of common concern (Wooten \& Hoffman, 2008: 138; italics in original). In a centralized organizational field, power, defined as the ability to influence other actors in the field 
(Reay \& Hinings, 2009; Reay \& Hinings, 2005), is concentrated in a relatively small number of organizations and individuals (Meyer, Scott, \& Strang, 1987). Conversely, decentralized fields are characterized by the absence of extremely powerful actors (Lounsbury, Ventresca, \& Hirsch, 2003) and the distribution of power across a wide array of stakeholders.

Because the organizations that comprise a field bring with them differing goals and means, multiple logics are often present within organizational fields (Greenwood et al., 2011; Kraatz \& Block, 2008; Thornton et al., 2012). In relatively centralized fields, the multiple logics that constitute the field may be characterized as dominant and subordinate. A dominant logic is granted priority in the practices, technologies, governance arrangements, and organizational forms of the most powerful actors in the field (Greenwood et al., 2010; Thornton \& Ocasio, 2008; Wry, Cobb, \& Aldrich, 2013). For example, public school systems that receive high levels of state funding are controlled by state governments, and thus are dominated by a state logic (Meyer et al., 1987). Although powerful actors may be aware of, and even have sympathy for, oppositional logics (Delbridge \& Edwards, 2013), they consistently pursue the means and goals prescribed by the dominant logic in order to maintain their position of authority. In contrast, a subordinate logic is prioritized by few, less powerful actors, and in a small number of relatively inconsequential governance arrangements (Marquis \& Lounsbury, 2007). For example, prior to the formation of the EPA in 1970, the logic of ecologizing enjoyed very low subscription in the U.S. chemical industry (Hoffman, 1999).

\section{Institutional Logic Incompatibility}

The multiple logics that constitute a field may be not only different, but also incompatible (Friedland \& Alford, 1991; Greenwood et al., 2011; Lounsbury, 2007). As Scott describes, "there is no question but that many competing and inconsistent logics exist in modern society" (1995: 130). Institutional logics designate "which means are meaningful" and which "means- 
ends couplets are thought appropriate" (Friedland, 2002: 383). They influence both the goals that actors find salient and the means selected to achieve those goals (Thornton, 2002). Logic incompatibility can arise as a result of differences between both the goals and the means associated with distinct logics (Pache \& Santos, 2010). Pache and Santos (2013), for example, describe how incompatibilities between market and social welfare logics create tensions within social enterprises. These organizations confront logic incompatibility because certain practices such as the use of paid professionals are more aligned with a market logic's means, yet may be incompatible with a social welfare goal.

Logic incompatibility can persist when actors perceive that the realization of the goals of one logic undermines the realization of the goals of another (Pache \& Santos, 2010). This is because "goals reflect core values and beliefs and are evaluated based on a logic of appropriateness, making them hard to challenge or modify" (Besharov \& Smith, 2014: 367). Logic incompatibility may also persist because the means specified by a logic are linked to resource commitments and path dependencies that prevent change (Pache \& Santos, 2010; $\underline{\text { Seo }}$ and Creed, 2002). Despite recognizing the existence and persistence of incompatible logics within fields, research has yet to explain how logic incompatibility evolves throughout time (Greenwood et al., 2011). Examining this process requires understanding of how actors respond to logic incompatibility and the effect of such actions on the relationship between logics within an organizational field.

\section{Organizational Responses to Logic Incompatibility}

Institutional scholars have described specific strategies used by organizations to manage tensions between logics (Oliver, 1991). These include compromise (Greenwood et al., 2011), contestation (Hargrave \& van de Ven, 2006), and hybrid organizing (Battilana \& Lee, 2014). 
When organizations compromise, they bargain with external constituents and make concessions to partially conform to the demands of proponents of incompatible logics. For example, health care firms may adhere to minimal standards of economic and caregiver logics (Scott, 1983), and micro-finance organizations compromise between development and economic logics (Pache and Santos, 2013). Compromise strategies can take a variety of forms, including the decoupling of practices from an organization's goals (Bromley and Powell, 2014). Prior work has examined the determinants of organizational compromise and decoupling (e.g., Oliver, 1991; Westphal \& Zajac, 1994; Zajac \& Westphal, 2004) but has paid less attention to the outcomes of these strategies. Because compromise implies partial conformity and does not fully resolve tension between logics, it may trigger subsequent changes in organizations and fields, rather than representing an end point.

Incompatible institutional logics may also incite actors to mobilize and engage in contestation through collective action (Hargrave \& van de Ven, 2006; Seo \& Creed, 2002; Waldron, Navis, \& Fisher, 2013). For example, research on social movements has largely focused on how a dominant institutional logic may be challenged and replaced, through advocacy efforts (McAdam, McCarthy, \& Zald, 1996). Framing plays an important role in this process (Lounsbury et al, 2003). Frames are "schemata of interpretation" (Goffman, 1974: 21) which "render events or occurrences meaningful and thereby function to organize experience and guide action" (Snow \& Benford, 2000: 614; see also Benford \& Snow, 2000; Gamson, 1995; Snow \& Benford, 1988). Like the symbolic elements of institutional logics, frames connect goals and motivations to strategies and means (Benford \& Snow, 2000). Following Fligstein (1996), Lounsbury and colleagues argue that "frame challengers engage in political struggles to either establish dominance within a frame or de-institutionalize a frame that impedes their interests" (2003: 76). Research by Rao, Monin, and Durand (2003) attests to this, showing that within the 
field of French cuisine, chefs began to abandon classical for nouvelle cuisine after activist chefs framed their roles in ways that were consistent with new and distinct identities. While the frames utilized by social movements have been shown to be instrumental to replacing logics (e.g. Waldron, Fisher, \& Navis, 2015), this literature tells us little of how logics may be integrated. Recently, scholars have recognized that organizations may combine multiple, often incompatible, logics through hybrid organizing (Battilana \& Lee, 2014). Research on hybrid organizations recognizes that incompatible logics may be re-framed as compatible within organizations. For example, Tracey et al. (2011) describe how entrepreneurs combined "the logic of for-profit retail and the logic of nonprofit homeless support" (69) to create the hybrid form of a for-profit homeless support organization. Mars and Lounsbury (2009) highlight how students embedded in the logic of environmentalism, and then exposed to entrepreneurship education, fostered organizations with “.... market-centered approach to both building successful businesses and advancing environmental causes" (7). However, while the literature on hybrid organizing offers new insight into how organizations deal with logic incompatibility internally through their culture, identity, and governance (Battilana \& Lee, 2014; Grimes, McMullen, Vogus, \& Miller, 2013; Miller, Grimes, McMullen, \& Vogus, 2012), it tells us little about how such organizations may influence field-level change or the hybridization of logics at the field level (but see Tracey et al., 2011).

\section{The Evolution and Hybridization of Field-level Logics}

To develop our process model of field-level logic hybridization, we build on prior literature that has shown how change in the relationship between field-level logics can follow two broad patterns: 1) developmental change, in which the majority of prevailing practices and symbolic relationships remain, and 2) transformational change in which radical shifts in practices and means-goal relationships are observed (Thornton et al., 2012: 164). 
In developmental change, a prevailing logic is reinforced, or minimally altered. One form of developmental change, elaboration, refers to the endogenous reinforcement of an institutional logic. In this process, "internal developments in institutional logics lead to new narratives and practices that further reinforce the prevailing logic" (Thornton et al., 2002: 167). For example, Shipilov, Greve, and Rowley (2010) show how organizations adopted new practices in board and CEO governance, to further reinforce a prevailing logic of shareholder value creation. In assimilation, dimensions of external logics are incorporated into a prevailing logic, yet "the core elements of the original logic prevail, with new practices and symbols made part of the prevalent logic" (Thornton et al., 2012:165 ). Murray (2010) finds that elements of a market logic, in this case patenting practices, were assimilated into the professional logic of academia as opposed to replacing or transforming it. Similarly, Arjaliés (2010) shows how the practice of socially responsible investing in France was assimilated within the market logic of the investment field. Of most interest for this study are more radical, transformational changes in field-level logics. In replacement an institutional logic is supplanted by an alternative logic (Thornton et al., 164). Much of the work on the replacement of one competing logic by another has focused on the motivations and social position of early and late adopters of new practices (Greenwood \& Suddaby, 2006; Leblebici, Salanci, Copay, \& King, 1991; Sherer \& Lee, 2002; Westphal, Gulati, \& Shortell, 1997). Other researchers have taken a more social constructionist perspective on logic replacement. For example, building on Suddaby and Greenwood's (2005) work on the role of rhetoric in institutional change processes, Lepoutre \& Valente (2012) show that the willingness to deviate from a dominant logic and enact a new logic is a function of one's implicit theory of change. Social movement scholars have portrayed logic replacement as a collective action process focusing on the role of framing in contestation, as discussed above. 
Another form of transformational change is blending. Blending has been described as “combining dimensions of diverse logics" (Thornton et al., 2012:164). For example, Glynn and Lounsbury (2005) describe how aesthetic and market logics were simultaneously used in the discourse of Atlanta Symphony reviewers in the wake of a musician's strike. Similarly, Smets et al. (2011) studied how a law firm began to incorporate elements of German and English law into their practices to better satisfy their client's interests. Blending broadly describes the coexistence of dimensions of multiple logics, but does not refer to the integration of incompatible logics (Battilana \& Lee, 2014).

Hybridization differs from blending in that the goals of incompatible logics are integrated as complementary; they do not merely co-exist. For example, Battilana and Dorado (2010) show how micro-finance organizations integrate development and banking logics as equally valid, complementary approaches to poverty alleviation. Contrary to assimilation, hybridization requires that the goals of distinct logics be constructed as simultaneously achievable, without granting dominance to one logic over another.

Hybridization processes change the relationship between incompatible logics, eventually leading to a new hybridized logic that integrates the incompatible logics. As with other institutional logics, we posit that a distinct hybridized logic emerges when it becomes embedded in organizational forms, material practices, and governance arrangements within a field. Surprisingly, while the concept of a hybridized field-level logic has been alluded to (e.g. Mars \& Lounsbury, 2009; Tracey et al., 2011), the process logic hybridization has neither been theoretically clarified nor given empirical attention. Thus, the question of how and when logic hybridization occurs at the field level, and even the definition of a hybridized logic, is a critical gap in our understanding of field-level change. 
This study seeks to build upon the literature on logic incompatibility and hybrid organizations reviewed above to develop a process model of field-level logic hybridization. Based upon the critical theoretical gaps identified in our literature review, we entered our field study with three research questions: (1) How can organizational responses to logic incompatibility and evolving field conditions lead to logic hybridization?; (2) What is the role of hybrid organizations in the process of field-level logic hybridization?; and (3) What distinguishes logic hybridization from related concepts?

\section{METHODS}

To conduct our research, we followed the process of theoretical sampling (Eisenhardt \& Graebner, 2007; Glaser \& Strauss, 1967) in which a case is selected because it is suitable for elaborating on the relationships between constructs of interest. As our goal was to outline the sequence of events that produces logic hybridization, we engaged in a process study (e.g. Elsbach \& Sutton, 1992; Langley, Smallman, Tsoukas, \& Van de Ven, 2013; van de Ven \& Poole, 1995) chronicling key events over time. We sought an empirical setting characterized by multiple organizational responses to logic incompatibility over time.

We engaged in an inductive study of the organizational field surrounding wind energy in Colorado for the period from 1999 to 2008. Wind energy gave us a clear issue of common concern and conflict at the field level (Wooten \& Hoffman, 2008). As we discuss in depth below, the wind energy field in Colorado was constituted by groups espousing incompatible logics, has undergone significant institutional changes, and was characterized by logic hybridization that integrated two previously incompatible logics over time. Our intent was to richly describe the existence of a pattern (Eisenhardt \& Graebner, 2007; Yin, 2002) to enable new theory building in the underexamined process of logic hybridization. 


\section{Data Collection}

We collected data using: (1) semi-structured interviews, (2) naturalistic observation, (3) keyword searches of newspaper articles, and (4) a wide variety of archival documents. We relied on our interviews as the primary source of data when exploring the incompatible logics espoused by actors within the field, as well as to delineate the motivations and strategies employed as organizations responded to logic incompatibility. The newspaper articles served as an important source of triangulating our interviews, and were our primary source of data when seeking to understand changes in field-level logics. We utilized the archival documents to understand fieldlevel changes, triangulating with the newspaper articles and interviews. The sources and uses of our data are summarized in Table 1.

\section{Insert Table 1 about here}

Semi-structured interviews. We conducted 34 interviews with 30 participants in the Colorado wind energy field, ranging from 60 minutes to three hours. To maintain consistency the lead author conducted all of the interviews. Initial interviews were garnered from contacting the National Renewable Energy Laboratory (NREL) in Golden, Colorado. From these initial interviews we utilized a snowball technique asking each informant who they believed could best help us understand wind energy in Colorado. The initial interview protocol was wide ranging, as we sought to gain understanding of the historical evolution of the field. Subsequent interviews included more focused questions as themes began to emerge from the data. To ensure that our informants were not led by our emergent insights, we only introduced our themes for validation after conducting the initial protocol. The last protocol used is provided in Appendix A.

We sought informants who were familiar with how organizations responded to the incompatible demands of field-level logics. Many of our interviewees occupied multiple roles 
over the period of our case study. For example, several individuals moved from environmental activism to government or industry positions. Our sample included founders of clean energy SMOs, which we describe below (3), founders of environmental SMOs (2), participants in clean energy SMOs (4), founders of wind energy firms (4), individuals who had experience as environmental activists and as government officials (2), an individual with experience as an environmental activist and entrepreneur (1), attorneys (2), NREL researchers (2), wind energy company employees (2), utility executives ranging from CEO to wind energy program manager (5), Colorado Public Utilities Commission (CPUC) Staff (2), and one ski resort Vice President of Sustainability (1). We interviewed three of our participants twice, on separate occasions, and conducted one round-table interview to follow up with a group of four utility executives. Interviews were conducted in person whenever possible on dates ranging from June, 2010 to April, 2014. Interviews were recorded and transcribed in 379 pages of single-spaced text.

Naturalistic Observation. We conducted multiple site visits to organizations involved with wind energy in Colorado. We visited NREL on three occasions $(2009,2010,2013)$ and the National Wind Technology test site in Colorado (2009). We also attended three annual meetings (2007, 2008, 2009) of the "Sustainable Opportunities Summit", sponsored by Connected Organizations for a Responsible Economy (CORE), a Colorado-based clean energy SMO. In addition, we engaged in site visits with two wind energy firms $(2010,2011)$ and two visits to Xcel Energy Headquarters in Denver $(2013,2014)$. These activities grounded us in the field and helped us to identify informants and verify our observations. For example, our snowball sample of social movement activists began with interviewing analysts at NREL. As we spent time at the CORE meetings, we became sensitized to the historic issues of contention in the field. By engaging in visits to Xcel, and sharing our emerging findings with them, we gained comfort that our depiction of the organization's historic actions and mindset was accurate. 
Newspaper articles. We engaged in in-vivo coding of 546 newspaper articles published in The Denver Post (Colorado's largest newspaper) between 1994 and 2010. These articles were identified through a search on the key terms "wind energy" and "renewable energy." Using these articles we constructed a timeline of the key events, revised with feedback from our informants.

Archival data. In addition to the Denver Post articles, we utilized archival sources of data acquired through proactive searching and provided by informants. First, we searched the CPUC website for archived news releases for the terms "wind", "wind energy", or "renewable." Second, using the Internet Archive (archive.org) we searched for mentions of "wind energy" or "renewable" on all archived webpages for two large Colorado electric utility companies (Xcel Energy and Tri-state Generation and Transmission). Third, we searched the CPUC web archive for all decisions pertaining to "wind" that impacted all major utilities in the state (Xcel Energy, Tri-State, Holy Cross, Intermountain Rural and Colorado Mining). Fourth, we obtained all available resource plans for each Colorado utility. Fifth, we collected archival documents from a variety of sources including environmental SMOs, utilities, and NREL. Finally, we viewed and selectively transcribed television news coverage of the Windsource program. These archival documents totaled 1,781 pages, single-spaced.

\section{Data Analysis}

All of our data were carefully managed utilizing computer-based qualitative analysis software (Nvivo 10). In addition, we maintained careful records of all documents and interview notes. As we engaged in the collection of these data we engaged in constant comparison (Siggelkow, 2007) between prior data collected and new observations. Once we had coded the Denver Post data and our initial interviews we prepared a draft timeline and narrative history of wind energy in Colorado and validated this draft with informants. We then followed established procedures for inductive research, particularly the tenets of grounded theory (Glaser \& Strauss, 
1967; Golden-Biddle \& Locke, 2007; Locke, 2001). We utilized portions of this timeline, and selective quotes from our early research as illustrative examples in a previously published quantitative analysis (Pacheco, York, \& Hargrave, 2014) that examined the co-evolution of social movements and the wind industry in the United States.

We began by creating in-vivo (Gioia, Corley, \& Hamilton, 2013; Glaser \& Strauss, 1967; Locke, 2001) first-order codes utilizing the language of our informants. The concept of a multilevel process through which field-level changes co-evolved with organizational actions emerged early, but the exact relationships remained unclear. We thus became aware that further review of the literature on institutional logics would inform our theory as we continued our analysis.

Two of the authors conducted the coding, with all three authors meeting regularly to discuss the emerging themes. In this way, one author remained the "outsider" and ensured the trustworthiness of our findings based on the evidence presented (Strauss \& Corbin, 1994). As themes emerged, we iteratively moved between the literature on institutional logics and our emergent data in triangulating between theory, key events, and codes (Gioia et al., 2013).

From this first-order coding we compiled an account of the events described in our timeline, paying particular attention to responses to, and changes in, field-level logics and centralization. We next began searching for relationships amongst our codes to group them into second-order themes. Consistent with the principles of grounded theory, we entered our analysis with a theoretical orientation towards understanding the role of responses to logic incompatibility in altering the organizational field; however, our insights emerged inductively from our coding (Yin, 2002). From the second-order coding we consolidated our 96 first-order codes to 13 themes. At this point, our theory had evolved to encapsulate the three overarching dimensions that comprise our data structure and process model. The final data structure is illustrated in Table 2, which summarizes the themes we utilized in building our model of logic hybridization. 


\section{WIND ENERGY IN COLORADO}

Through our examination of the data, we developed a multi-level model that moves between the actor and field levels. This model has three dimensions and is illustrated in Figure 1. This model captures the recursive relationship between: (1) organizational responses to logic incompatibility (actor level), (2) changes in the relationship between logics (field level), and (3) field centralization (field level). We now explain how each of these dimensions, and sub-themes within them, emerged as we examined the field of wind energy in Colorado.

\section{Insert Figure 1 about here}

\section{Logic Incompatibility and Conflict: Economizing versus Ecologizing}

In the beginning of our case study period, discussion in Colorado focused on whether wind energy could economically compete with carbon-based sources of energy. Colorado relied on its abundant coal and natural gas resources, which are attractive from an economic perspective, but have deleterious impacts on air, water, and land. Although some organizations promoted wind energy for its environmental benefits, debate centered on wind energy's economic viability and ability to compete with fossil fuel resources:

Colorado's growth has created unprecedented demand for electricity, which Public Service has largely met through use of coal, which meets more than 93 percent of our needs. Coal is clean, abundant and cheap and sufficient to meet our needs for several hundred years.... Wind power is not reliable....coal is the key to Colorado's energy needs. (The Denver Post, Wattenburg, 1998)

A similar argument was repeatedly espoused by Colorado's investor-owned electric utilities. One utility executive articulated his opposition to wind energy as follows: 
The bill (supporting wind energy) would do little, if anything, ... to improve air quality. In truth, it is a Trojan horse for unprecedented government interference in energy markets that, if enacted, could worsen Colorado's energy crisis by raising energy costs for industrial and residential consumers alike. (The Denver Post, Sanderson, 2004)

This focus on economic costs, and lack of concern for environmental impacts, reflects a logic of economizing. In describing an economizing view, Frederick writes, "few beliefs are more deeply embedded in the modern business firm" (1995: 143). The goals of the economizing logic are linked to the ideals of efficiency, wealth creation, and speed. An economizing view of the human-environment relationship sees the natural environment as a resource to be used efficiently by business. These goals are in turn manifested in means that measure and prioritize economic profit. In the beginning of our case, economic goals were instantiated in fossil fuelbased technologies such as coal-fired power plants, which were considered an appropriate means towards achieving greater economic efficiency. The goals of economizing were also embedded in the governance of Colorado's electricity industry through the CPUC. This regulatory agency consists of three commissioners appointed by the Governor and confirmed by the state senate. The CPUC oversees the rates and resource plans of all utilities and was charged by state law to require utilities to seek the "least-cost" option for energy production (Schmitz Consulting, 2008).

In response to growing air pollution surrounding Denver and other areas throughout the front range of Colorado, environmental SMOs began to challenge the dominant logic of economizing in the early 1990s. For example, the Boulder-based Western Resource Advocates (WRA) was founded as Law and Water (LAW) Fund of the Rockies ${ }^{1}$ to "...protect the West's land, air and water...(and) advance clean energy to reduce pollution and global climate change" (Western Resource Advocates, 2011). WRA and other environmental SMOs in Colorado espoused a logic of ecologizing, emphasizing interdependence and maintenance of relationships

\footnotetext{
${ }^{1}$ Although quotes may refer to Western Resource Advocates as "WRA", "Land and Water Fund", or "LAW Fund" we refer to this organization as "WRA" throughout the text for the sake of simplicity.
} 
that perpetuate human and natural communities (Frederick, 1995). An ecologizing logic prioritizes goals of environmental preservation, and recognizes nature's inherent moral value. Practices that improve environmental conditions, such as renewable energy, are theorized as means to achieve these goals. Wind energy development aligns with an ecologizing logic because it does not have the negative environmental impacts associated with fossil fuel-based energy, which is associated with air pollution and climate change (IPCC, 2011). An article in the Denver Post articulated SMOs' ecologizing logic for wind energy:

Wind advocates say that head-to head cost comparisons of wind versus fossil fuels fail to take into account wind's environmental benefits... Wind produces no smog and adds nothing to global warming, unlike coal-fired power plants that produce greenhouse gases and volatile organic compounds, they note (The Denver Post, Raabe \& Bunch, 2003).

Environmental SMOs, led largely by WRA, began to lobby the state legislature to force utilities to adopt wind energy. However, proponents of an economizing logic, specifically utilities and the CPUC, viewed wind power as an expensive, unreliable technology which conflicted with the goal of economic efficiency.

Incompatibility between ecologizing and economizing logics is common in energy and environmental policy debates. Frederick (1995) argues that the "ethical fault lines" between economizing and ecologizing "generate enormous normative tensions that pose questions of fundamental import for the future of business and society relations" (135). Hoffman (2011) asks whether the "schism" between the market logic of actors who are skeptical of climate change and the more communitarian logic of those who are convinced that climate change is real is now so great that it may be irreconcilable (also see Gladwin et al., 1995, Hoffman, 1999; Hoffman et al., 1999; and Wade-Benzoni et al., 2002). Table 3 clarifies the conflict between the symbolic and material elements of economizing and ecologizing logics, providing ideal types and examples of how the logics were espoused in our data. 
At the beginning of our case, economizing was the dominant logic of the Colorado wind energy field. As Figure 2 shows, our coding revealed that statements based in an economizing logic appeared with double the frequency of those espousing an ecologizing logic in 1998. Further, there was no utility-scale wind energy in Colorado and activists had twice failed in efforts to establish renewable energy requirements. "By fall of 1996," activists concluded, "there was no viable path for developing regulatory policies to support renewable resources in Colorado" (Mayer, Blank, \& Sweeney, 1999:3).

\section{Insert Figure 2 about here}

The efforts of Colorado environmentalists to challenge the dominant logic of economizing were made difficult by the centralization of the wind energy field in Colorado around powerful actors who espoused the logic of economizing. One of these was the chief governing organization, the CPUC, discussed above. The other was the largest utility, Public Service Company of Colorado (PSCo), a subsidiary of Xcel Energy ${ }^{2}$, which held a 55 percent market share and serviced the majority of Colorado's population (Komor, 2006).

Logic incompatibility, combined with high field centralization, set the initial conditions in our study. We now examine how organizations reacted to this setting, and how these actions recursively influenced changes in both field-level logics and in field centralization. In presenting these findings we utilize six integrated data displays: Table 2 showing the finalized data structure, Figure 1 showing key events and the induced process model, Figure 2 showing key measures over time, and Tables 4-6 which provide examples of data for each major theme.

\footnotetext{
${ }^{2}$ Although quotes refer to both "PSCo" and "Xcel", in the text we refer to the utility and its subsidiary as "Xcel" for the sake of clarity.
} 


\section{Insert Tables 4-6 about here}

\section{Compromise Leading to Elaboration: The Windsource Program}

By 1997, environmental SMOs had become frustrated with their inability to encourage wind energy adoption in Colorado. As described above, the CPUC and Xcel were largely unreceptive to the ecologizing arguments offered by SMOs. A WRA leader described his organization as “just exhausted from fighting them [Xcel \& CPUC]." WRA and other environmental SMOs decided to accept Xcel's offer to engage in a collaborative effort, to foster a voluntary "green pricing” program. Originally conceived by Xcel as a compromise in past regulatory battles, the Windsource program offered customers the option to pay a price premium to purchase electricity produced from wind energy. Windsource was the first investor-owned utility program in the U.S. to offer wind energy directly to consumers and a unique collaboration between the utility and SMOs. WRA announced it was "coordinating the efforts of...Boulder Energy Conservation Center, the Colorado Renewable Energy Society, and the Sierra Club [which] will include articles about Windsource in their newsletters and will potentially use their mailing lists to further promote the program" (Mayer, Blank, \& Swezey, 1999: 12).

From the utility's perspective, Windsource was of little cost, presented no risk, and generated an entry into wind energy. Further, an earlier marketing study had suggested that their customers were interested in, and willing to pay a premium for, wind energy. However, just as it represented a compromise for environmentalists who preferred wind energy mandates as a means of achieving their ecologizing goals, the program also represented a compromise for the utility, because incorporating wind energy into its portfolio contradicted its standard practice of achieving its economizing goals through fossil fuel-based practices. 
Change in Field Conditions: Elaboration. While this compromise approach to logic incompatibility required Xcel to partially conform to demands for wind energy by adopting new practices, the program had the effect of elaborating the dominant economizing logic at the field level. Windsource was not a departure by Xcel from the goals of economizing nor an attempt to reduce logic incompatibility at the field level; the program was, and remains as of this writing, a decoupled program that is justified as a "premium” product. As Xcel's CEO reflected, “...we would build as many wind turbines as customers are willing to pay for" (Xcel Energy, 2004). Table 5 offers additional examples of how an economizing logic was elaborated through Windsource.

Frustrated that the design and public justification of Windsource elaborated the goals of the logic of economizing, some environmental advocates opposed the program. They recognized that Windsource was not a means of promoting the goals of ecologizing, and therefore viewed it “as being a poor substitute for regulatory requirements funded by all customers" (Mayer et al., 1999:3). In sum, logic incompatibility was not reduced through the compromise because the goals of economizing and ecologizing logics continued to be constructed as incompatible. Table 4 provides additional examples of how Xcel and environmental SMOs remained fully embedded in the conflicting logics of economizing and ecologizing, while engaging in compromise.

While Windsource did not significantly alter the centralization of power within the field, it did increase the "credibility [of environmental activists] in the eyes of individuals, businesses, local governments, and the media" (Mayer, Blank, Udall, \& Nielsen, 1997). In addition, the program generated a great deal of media attention for both Xcel and SMOs. This coverage raised the public profile of SMOs and often portrayed them not only as advocates for wind power but also as important partners of Xcel in provisioning it. Raising the profile of environmental SMOs in Colorado was an unintended consequence with significant implications for Xcel. 


\section{Reframing Leading to Assimilation: The Lamar Wind Farm}

In 1999 Xcel filed a resource plan for CPUC approval that included a request for

proposal for new electricity supply. Among the received bids was a proposal for a $162 \mathrm{MW}$ wind farm located near Lamar, Colorado, which Xcel rejected in an "economic decision based on the cost of power." It reasoned that "wind power will be more expensive than natural gas-generated electricity" (The Denver Post, Booth, 2001).

Environmental SMOs, including WRA, responded to this continued elaboration of the economizing logic by reframing wind energy. Rather than challenging the decision on ecological grounds, wind advocates adopted frames that were consistent with economizing goals, justifying the proposed wind farm on the basis of cost. Their analysis showed that wind power could be generated at two cents per kilowatt-hour less than a new natural gas plant (Raabe, 2001). CPUC commissioners sided with the SMOs' analysis, concluding that the wind farm was cost effective:

We find that adding... (the) Lamar wind energy bid to PSCo's preferred resource plan is in the public interest...This determination is based solely on our finding that the acquisition of the Lamar facility will likely lower the cost of electricity for Colorado's ratepayers. After a careful analysis of the economics of the wind bid, we find that it is justified on purely economic grounds... (CPUC, 2001a).

The SMO's reframing involved strategic appropriation of the goals associated with the dominant logic to advance the practice of wind energy. This reframing was made possible through the prior learning SMOs gained through the Windsource compromise. As shown in Table 4, SMOs learned to "speak the language of business" (Mayer et al., 1999). However, SMOs continued to utilize an ecologizing logic to critique utilities' overall record:

"These are people who burn stuff," Lehr said. 'They are essentially an outlet for the primary fossil fuel extraction industries - coal, oil and gas. That's what they do. That's what they understand." (The Denver Post, Booth, 2001)

Change in Field Conditions: Assimilation. Environmental SMOs' reframing did not integrate the goals of economizing and ecologizing logics. Rather, the Lamar decision resulted in the assimilation of the means of the subordinate ecologizing logic (wind energy) into the goals of 
the economizing logic (low cost energy) that still dominated the field. Wind energy was justified on purely economic terms. Powerful actors in the field (CPUC) recognized the need for renewable energy but only in cases in which it was the most economically effective option. While this shift was partially driven by technical improvements that reduced the cost of wind power, ${ }^{3}$ it occurred only after environmental SMOs challenged the Lamar decision by employing an economizing frame. The CPUC demonstrated its continued commitment to an economizing logic by explicitly stating "we ... adopt rules based on least-cost criteria alone" (CPUC, 2002). As Table 5 shows, the logic of economizing continued to dominate all formal conversations and decisions in the field, limiting the growth of wind power to a fraction of the potential SMOs envisioned. While environmental SMOs again bolstered their legitimacy, authority continued to be centralized with the CPUC and Xcel. This centralization of power was to be significantly reduced in the next phase of wind energy development in Colorado.

\section{Contestation Leading to Field Expansion: Amendment 37}

Angered from their "ten-year-long litigation and frustration experience" (interview with Clean Energy SMO leader), environmental SMOs sought to foster a larger alliance to advocate for a state-level renewable energy portfolio standard (RPS). An RPS passed by the state legislature would mandate that utilities generate a defined percentage of their energy portfolio from renewable resources. Such a mandate would significantly increase wind energy generation in Colorado beyond the "least cost" scenario.

\footnotetext{
${ }^{3}$ From 2001-2002, the national price of wind power based on capacity weighted average decreased by about $28 \%$ (compiled from Wiser and Bolinger, 2012). Despite these reductions, these figures remained relatively stable until 2009 when price increased again. Throughout the time period of our case, significant uncertainty remained on the ability of wind power to be competitive with fossil fuel-based electricity generation (Bolinger, 2010); to this date, the industry heavily depends on production tax credits to infuse development and growth (Wiser \& Bolinger, 2012). In addition, the competitiveness of wind power prices depends on how prices are measured (Wiser \& Bolinger, 2012). As Figure 2 illustrates, when measured through national capacity weighted average by purchase power agreement dates (which is how Xcel Energy obtains most of its wind power), price figures actually increased from the years 2004-2009 (as compiled from Wiser \& Bolinger, 2012). Therefore, while in the Lamar farm decision wind energy was considered the least cost alternative, this was not a universal conclusion, and varied over the time of our case study.
} 
To promote the RPS, environmental SMOs devised a slogan, "Colorado needs cleaner air and cheaper energy" (The Denver Post, Olinger, 2004), which included both economizing and ecologizing logics. They took this approach because they concluded from their Windsource and Lamar experiences that they could not achieve their goal of establishing significant wind power development in Colorado unless they: 1) took action at the state level rather than engaging on a costly case-by-case basis, 2) began to promote the benefits of wind power development in ecologizing terms, rather than allowing the economizing logic to dominate, and 3) reduced the concentration of power in the hands of Xcel and the CPUC (Olinger, 2004). Table 4 provides additional examples of the motivations for SMOs' decision to challenge utilities through legislative efforts under the "Contestation" heading.

Xcel and other utilities largely met efforts to promote RPS by arguing that renewable energy should be developed only when it offered economic benefits, and that much of the development required by the RPS would not be economically viable. Efforts to enact RPS legislation in both 2002 and 2003 failed. Wind advocates switched tactics in 2004, deciding to pursue an RPS by ballot initiative (a direct vote by Colorado citizens) rather than through the state legislature. One environmental SMO activist told us, “...we just got frustrated and... we have a record in Colorado of taking the issues that the legislature is not dealing with directly to the vote of the people."

A coalition of SMOs led the campaign for Amendment 37, which would require utilities to acquire ten percent of their energy from renewable sources by 2010 and twenty percent by 2022. By utilizing both economizing and ecologizing arguments, environmental SMOs built a broad coalition including “...many traditionally conservative entities like the farmer's union and others in the farm movement and agricultural industry" (Clean Energy SMO Board Member). Many other proponents were involved in the collection of the 60,000 required signatures to put 
Amendment 37 on the ballot, including various cities in Colorado, economic development councils, unions, and the ski industry (Komor, 2006). The ballot initiative was opposed by utilities in the state, again based on an economizing logic. As Xcel articulated their position on the corporate website:

We work hard to keep prices competitive. And we are especially careful to ensure that our customers don't bear the burden of a certain class of expensive renewable technologies. For example, there will be an initiative on the November ballot in Colorado for a renewable energy mandate...we're concerned about the potential price impact that this initiative could have on our customers. (Xcel Energy, 2004)

Amendment 37 passed by a 54 percent vote in November of 2004, making Colorado the first state to create an RPS through a ballot initiative.

Change in Field Conditions: Reduced Power Concentration. Amendment 37 created regulatory legitimacy (Hiatt, Sine, \& Tolbert, 2009; Scott, 1995) for an ecologizing logic at the state level. Failed attempts to validate an ecologizing logic through compromise with electric utilities (Windsource) and reframing to regulators (Lamar decision) provoked SMOs to engage in contestation by employing both economizing and ecologizing arguments to advance their claims. One leader of the Amendment 37 ballot initiative told us:

We talked about basically three message points that we were using. One is that wind was economical... Two, it was really good for economic development, particularly in the rural areas where, even though Colorado had been going through a boom at that time, these rural areas were in many ways left behind... and the third piece was this was good for the environment as well. (Environmental SMO Leader)

Wind energy advocates failed to pass a renewable energy standard in the Colorado legislature, and were only successful when they expanded the field to include a broader coalition, and eventually, the citizens of Colorado. This strategy is illustrative of how, in centralized fields, incompatibility between institutional logics may motivate proponents of a subordinate logic to try to alter the balance of power in the field (Hiatt \& Park, 2013; Seo \& Creed, 2002). Figure 2 shows the increased use of hybrid statements, integrating economizing and ecologizing arguments for wind energy in the wake of Amendment 37. As an environmental activist described: 
...we used to say that the power to choose where your power comes from is now a decision made at the living room level instead of the board room level... and then you go through Amendment $37 \ldots$ Amendment 37 's the voice of the people... Every time the public, or somebody outside that regulated monopoly, regulatory structure, has an opportunity to say it, they're like, 'Yes, do more. Yes please. Keep going.' (Environmental Activist/Wind Energy Executive)

\section{Legitimation and New Forms: The Role of Hybrid Organizations}

By reducing field centralization and fostering regulative legitimacy for an ecologizing logic for wind energy, environmental SMOs created an opportunity for entry by new organizations, including wind energy entrepreneurs and clean energy SMOs. As we describe below, these two sets of organizations played a critical role in establishing and building legitimacy for new linked frames, practices, and arrangements which incorporated the goals of both economizing and ecologizing, and which were to become the elements of a hybrid logic for wind energy in Colorado.

The establishment of the ecologizing logic within the organizational field's governance structure through the RPS delivered sociopolitical legitimacy—acceptance by key constituents of the industry's practices, outputs, or goals (Aldrich \& Fiol, 1994) - to wind energy entrepreneurs. Sociopolitical legitimacy is particularly important in emerging industries, which often confront the liability of newness (Aldrich \& Fiol, 1994; Scott, 1995) and must gather support from powerful actors to gain acceptance (Stinchcombe, 1965). This legitimacy in turn increases the ability for new firms to access critical resources such as funding and employees (Zimmerman \& Zeitz, 2002; Zott \& Huy, 2007), and thus encourages growth. As outlined in Figure 2, the average number of clean energy firm foundings in Colorado prior to 2005 was 11.5; from 20052009 the average number of entries tripled to 35, creating 261 new entrants since 2005 (CORE \& Levenson, 2009). An Amendment 37 campaign leader observed:

\footnotetext{
What's really struck me is that right after Amendment 37 passed, everybody became a wind developer... if you wanted to make your name in Colorado, for a long time it was real estate and development. Then it became wind... there was a big land rush where lots of people were going out and locking down areas for wind development...it just fed on itself. (Environmental SMO Leader)
} 
By pursuing economic profits through environmentally beneficial technology, wind energy entrepreneurs tied means that had been associated with an ecologizing logic to the goals of the economizing logic. This was an important step in the hybridization of logics, because it linked a single set of practices to dual goals that previously had been perceived to be incompatible. One environmental activist characterized the wind energy industry as “...good for the environment but also good for the economy. This is like the ultimate win-win and it can't just be one or the other. It's really got to be both. That's the thing that gives its pizzazz."

After the passage of Amendment 37 wind energy advocacy shifted from a focus on broad environmental goals to a more developmental, wind energy industry-specific agenda. A group of SMOs with specialized knowledge and capabilities emerged to play this role. We refer to these organizations as "clean energy SMOs" because they advocated specifically for "clean" energy sources, including wind energy (Pacheco et al., 2014). Unlike traditional environmental SMOs, clean energy SMOs established identities, beliefs, goals, forms, and practices that combined the logics of economizing and ecologizing. As Figure 2 shows, from 1998 to 2009, clean energy SMOs in Colorado grew from nine to 25 (from authors' data compiled from the National Center for Charitable Statistics).

Clean energy SMOs played a unique role in advocating for wind energy. One wind energy firm founder noted that because of time and resource constraints, wind power companies did not "engage directly in advocacy and instead let the NGOs be the ones fighting for increasing the RPS or increasing transmission planning." Nor could existing environmental SMOs play this role because they did not possess the legitimacy and knowledge needed to engage in specific issues, such as business development and economic incentives. One founder of the Interwest Energy Alliance stated that "We strongly support most of the goals that our environmental allies 
advance but ...we're more business-oriented, in a nutshell." Within the "Legitimation" theme, Table 4 provides additional examples of clean energy SMOs' activities.

Clean energy SMOs stimulated the development of a hybrid logic in Colorado's wind energy field by arguing that wind energy could simultaneously - and not partially - achieve both ecological and economic goals. Their vision went well beyond the idea that wind had a place in a field in which economizing was the dominant logic; rather, they began to re-construct the relationship between economizing and ecologizing as compatible. They did so by establishing and disseminating a new frame, "the clean energy economy," which made sense of, and provided normative legitimacy for, the emergence of the wind energy industry. This new frame connected the goals associated with the economizing and ecologizing logics to each other, as well as to a single set of means, wind and other forms of clean energy. We found numerous examples of clean energy SMOs promoting the new clean energy logic and associated practice of wind energy through organizing press-friendly events, and directly editorializing in The Denver Post:

Colorado stands at the center of a metaphorical "harmonic convergence" of global energy trends and both national and state energy policies. If the legislature responds to this fleeting opportunity ...Colorado can add jobs in economically depressed areas and buttress our energy security - while taking the point in the worldwide struggle against global warming. (The Denver Post, 2007)

Clean energy SMOs often paired this symbolic work with employing their in-house technical expertise to foster the adoption of renewable energy technologies and practices. For example, the Colorado Clean Energy Cluster's (CCEC) worked to "attract, incubate and grow clean energy enterprises" in order to "catalyze economic vitality and generate community and environmental benefits" (CCEC, 2012). 4CORE offered training sessions featuring best practices for professionals in renewable energy. Similarly, CCEC fostered the creation and dissemination of knowledge through "research \& workshops to assess smart grid workforce readiness and provide workforce training support to clean energy companies"... and sponsored a "Utilities Summit to discuss impacts of smart grid and distributed resources to electric utilities" (CCEC, 
2012).

Clean energy SMOs also helped to establish new governance arrangements that promoted and legitimated the new clean energy frame and associated practices, including wind energy. From 2006 to 2010, 16 separate pieces of wind energy legislation were passed in Colorado (DSIRE, 2010; Office of the Governor of Colorado, 2010). These bills established tax incentives, rebates, and government grants. A CPUC Commissioner attested to the role of the clean energy SMOs in constructing the new, linked policies, markets, and technologies which constituted the emerging clean energy hybrid logic for wind energy, saying:

... they know how to connect the dots. They can see that policy is very important. But you've got...to have the right markets. You've got to have the right kind of technology out there ... they interact closely with legislators. (CPUC commissioner)

Change in Field Conditions: Hybridization. Clean energy SMOs played a key role in the hybridization of economizing and ecologizing logics. These organizations established and built legitimacy for a new set of interlinked symbolic elements (shared beliefs and goals) and material elements (practices, governance arrangements, and organizational forms) that integrated logics previously perceived as incompatible. According to the emerging clean energy frame, wind power was constructed as simultaneously "good for the environment, and good for the economy" (interview with clean energy SMO founder). As Table 3 illustrates, this hybridized logic had distinct goals, governance, and practices that differentiated it from both economizing and ecologizing logics. Table 6 provides examples of how organizational entry by wind developers and clean energy SMOs expanded the number of stakeholders in $\mathrm{CO}$ wind energy, further decentralizing the field, and setting the stage for embedding a hybridized logic across the field. 


\section{Embedding: Institutionalization of a Hybridized Logic for Wind Energy}

In the final stage of the logic hybridization process, the new logic was embedded in the

field. Embedding refers to active infusing of the foundations of an institutional logic into practices and arrangements (Lawrence and Suddaby, 2006). Whereas in the legitimation stage clean energy SMOs and wind entrepreneurs began to establish a limited set of new hybrid practices and arrangements that instantiated the clean energy frame, in this final stage of the process, a hybridized logic was institutionalized throughout the organizational field. Clean energy SMOs continued to play a role in this embedding process. For example, CCEC established formal partnerships with organizations such as Colorado State University, the city of Fort Collins, and clean energy companies to embed these hybrid practices into the educational, governmental, and business sectors.

In the final stage of logic hybridization, even actors who had most strongly held an economizing view adopted a hybridized logic integrating economizing and ecologizing logics. For example, Xcel published a "triple bottom line" report in 2007 (prominently featuring a wind turbine on the cover) proclaiming the utility's vision was to "be a responsible environmental leader, while focusing on our core business - reliable and safe energy at a reasonable cost” (Xcel, 2007:2). The report emphasized Xcel's view of environmental and economic goals, as linked symbiotically to its core business:

Our corporate strategy, called Building the Core, has three primary focuses: 1) being an environmental leader, 2) achieving our financial objectives and 3) efficiently managing our operating utilities. Our objective is to embrace growing customer demand and environmental initiatives by investing in our core utility businesses and earning a reasonable return on our invested capital. (Xcel Energy, 2007:24)

In addition to stating these beliefs, Xcel engaged in practices consistent with the new hybridized logic. For example, in the 2008-2015 resource plan for Colorado, Xcel detailed plans for acquiring over $800 \mathrm{MW}$ of wind energy, achieving a ten percent $\mathrm{CO}_{2}$ reduction by 2017, while keeping incremental costs to less than two percent (Xcel 
Energy, 2008). CEO Dick Kelly described wind energy as meeting “...needs of

customers, shareholders, environmental groups, regulators” (Xcel Energy, 2008:5).

The embedding of a hybridized logic for wind energy in Colorado is perhaps best

illustrated by Governor Bill Ritter's (2007-2011) successful campaigning, and subsequent focus

on, a "New Energy Economy" platform (Office of the Governor of Colorado, 2010). In 2007,

Governor Ritter's office issued a strategic plan for renewable energy in Colorado in which the

Governor stated, "We can reduce global warming and keep our economy strong and

vibrant...Developing new sources of clean renewable energy will grow the New Energy

Economy in Colorado" (Ritter, 2007: 2). To ensure the role of the CPUC in "building a clean

energy economy", Governor Ritter appointed Matt Baker, former Director of Environment

Colorado and leader of the Amendment 37 campaign, as the CPUC Commissioner:

"I am honored to be selected by Gov. Ritter for this position," said Baker, executive director of Environment Colorado. "Colorado is at a point where we can grow our economy, protect our environment and provide an affordable energy supply to the people and businesses of Colorado..." (Office of the Governor of Colorado, 2008)

Further embedding of the hybridized logic was enforced through governance

arrangements focused on the expansion of wind energy, as described in the Denver Post in 2007:

A bill to double Colorado's mandatory renewable-energy standard sailed through a House committee Tuesday on unanimous, bipartisan vote. The legislation is considered a cornerstone of Gov. Bill Ritter's call to make Colorado a national leader in alternative energy. Supporters said the bill protects consumers from volatile coal and natural gas prices, cleans the air, and provides jobs from renewable energy projects.

"This bill challenges the old idea that the environment and the economy can't prosper at the same time, "said Will Coyne of advocacy group Environment Colorado....

"We believe (this bill) will really be a big step in making Colorado a leader in renewable energy and the new energy economy," said Pat Vincent, president and chief executive of Xcel Energy's

Public Service Co. of Colorado. (The Denver Post, Raabe, 2007) 


\section{DISCUSSION}

This study sought to increase understanding of the hybridization of field-level logics through a historical analysis of the wind energy field in Colorado. It is, to our knowledge, the first to examine the process of logic hybridization. Our process model offers several theoretical contributions.

First, we distinguish logic hybridization from similar concepts such as blending and assimilation, and offer a specific, tractable, and useful definition of hybridized logics for future theory building. Second, we show that logic hybridization is a recursive process between organizational responses and changes in field conditions. Contrary to the existing literature, our model suggests that successful compromise and contestation are not end points in field evolution but rather potential triggers for entry by new, hybrid organizations. When proponents of a subordinate logic gain legitimacy and learning through compromise, reframing, and contestation, they may successfully decentralize fields and set the conditions for entry by new organizations. Third, our case illuminates the critical role of hybrid organizations in this process, showing how they embody, legitimize, and embed the symbolic goals and material elements that came to constitute the hybrid of two conflicting logics. Thus, we expand the extant literature on hybrid organizations that has largely focused on organizational level outcomes (e.g. Battilana \& Dorado, 2010; Mars \& Lounsbury, 2009; Pache \& Santos, 2013; Wry, Lounsbury, Jennings, 2013). We now elaborate on each of these contributions.

\section{Differentiating Logic Hybridization}

While the institutional logics literature has alluded to logic hybridization, it has not provided clarity regarding the concept's definition. Through our examination of the wind energy field in Colorado, we differentiated hybridization from previously offered concepts of combining institutional logics. In contrast to blending, which involves changes in discourse and practices to 
incorporate existing elements of multiple logics (e.g. Glynn \& Lounsbury, 2005; Smets et al., 2011), and assimilation, which in our case involved the attachment of the means previously only associated with a subordinate logic to the goals of a dominant logic, this study revealed a process in which actors construct specific new frames, practices, and arrangements that integrate previously incompatible goals. While prior research has theorized logics that reconcile economizing and ecologizing (Frederick, 1995; Gladwin et al., 1995) or shown such a logic operating at the organizational level (Gao \& Bansal, 2012), this study reveals the hybridization processes through which such logics are constructed within a field.

New governance arrangements, such as the unopposed increase in the RPS and the "clean energy economy" frame, were also deeply embedded in the field. Beyond aggregating specific dimensions of the ecologizing logic represented by SMOs (e.g., reducing $\mathrm{CO}_{2}$ emissions) with dimensions of an economizing logic proposed by the CPUC and utilities (e.g., profitable electricity generation), the hybridized logic that emerged in Colorado offered wind energy as the means to integrate the previously incompatible goals of economizing and ecologizing logics. As a result, we conclude that the formation of a hybridized logic is dependent upon the reduction of the incompatibility between the goals of previously incompatible logics, through specific means. Following the literature on hybrid organizing (Battilana \& Dorado, 2010; Battilana \& Lee, 2014; Besharov \& Smith, 2014; Smith, Gonin, \& Besharov, 2013) we propose that it is this integration of the goals of previously incompatible logics through the creation of a new logic that differentiates a hybridized logic. We also distinguish hybridization from assimilation, which is a form of blending but does not align conflicting logics. As we detailed above, assimilation in our case involved the attachment of the means previously only associated with a subordinate logic to the goals of a dominant logic. Logic assimilation took place when the CPUC enforced the adoption of wind energy in service to the "least cost alternative" mandated by an economizing 
view. While the adoption of wind energy may have helped to achieve ecologizing goals, the logic overriding the field remained firmly embedded within an economizing view that embraced wind energy only in a limited manner. Whereas compromise entails concessions to competing goals and the adoption of some means but deletion of others, hybridized logics do not involve concessions, but rather posit that the goals of competing logics can be aligned through the adoption of new, specific means.

It is important to note that while the price of wind power did decrease over time (see Figure 2), and this undoubtedly eased the transition, the actual practice of wind energy development changed very little over the course of the case. Throughout this time period, the future of wind energy continued to face uncertainty due to technical and economic circumstances (Vasi, 2011). Wind energy's ability to compete with fossil fuel-based sources continued to be questioned as illustrated by the industry's dependence on a federal production tax credit (Bolinger, 2010). What did change is that wind energy shifted from being framed as a means for ecological sustainability to a potential means for low cost electricity production, and finally, as the means to simultaneously protect the environment and the economy of Colorado.

\section{A Process Model of Logic Hybridization}

According to our model, a hybrid of incompatible logics is the outcome of processes involving the interplay of organizational responses and field-level conditions. By linking fieldlevel change to agency, we respond to recent calls to explain "field creation and change ... not ... as an exogenous event, but as something that is socially constructed by organizations via their decision-making and their ongoing and cumulative responses to institutional complexity" (Greenwood et al, 2011: 357). In our case, the reduction of field centralization and the gradual change in the relationship between field-level logics enabled actors to enact further changes, and ultimately led to the emergence of a new hybridized logic. Without these earlier processes, it 
seems unlikely that the field would have evolved to support the wind energy entrepreneurs and clean energy SMOs that instantiated the hybridized logic.

Our findings suggest that logic hybridization is an emergent process. There were numerous interdependencies in the process, as organizational actions triggered subsequent changes, both intended and unforeseen. These interdependencies prevented actors from predicting outcomes with certainty. Therefore, rather than planning for long term objectives, actors continuously adapted to their new environments through different organizational strategies. Whereas social movement scholars portray social change as produced through intentional efforts by movement actors using established "repertoires of contention" (Tilly, 1986) to replace formerly dominant logics (McAdam et al., 1996; McAdam, Tarrow, \& Tilly, 2001), this study shows that radical change at the field level may occur through ongoing experimentation and numerous unintended changes. In our case, a hybridized logic eventually developed in a fluid and emergent way out of a complex process. While our findings are derived from a unique context, they suggest a broader, generalizable set of insights for logic hybridization at the field level. We posit that a hybridized logic is likely to emerge through: 1) attempts at field-level collaboration by proponents of incompatible logics, and/or 2) escalating contestation and resultant field decentralization.

First, related to a gap identified by Bromley and Powell (2014), our research speaks to the field-level consequences of organizational decoupling and other forms of compromise. In the Windsource compromise, the means of wind energy was utilized by Xcel to support the goals of economizing; therefore, the goals of ecologizing and economizing remained incompatible from the perspective of environmental SMOs. As Ashforth and Reingen observe, compromise is "a choice of half of one and half of the other, integration involves both/and" (2014: 506). Our findings suggest that, even in successful programs such as Windsource, compromise through 
decoupling may not resolve conflict between representatives of incompatible logics because it does not integrate the goals of the two logics (Hallett, 2010; Sauder \& Espeland, 2009).

Rather, compromise can elaborate the dominant logic and preserve the power of dominant actors. In highly centralized fields, powerful actors espousing dominant logics are able to maintain autonomy over decision making (Battilana, Leca, \& Boxenbaum, 2009) and the status quo (Leblebici, Salancik, Copay, \& King, 1991). When logic incompatibility persists and the field remains centralized, dominant actors may continue to reinforce their preferred logics even when engaging in compromise. However, an unintended consequence of Windsource for Xcel was the creation of a more effective opponent. Windsource enabled environmental activists to achieve greater legitimacy in the eyes of the public and to learn how to reframe wind energy in economizing terms. These findings suggest that compromise, and other organizational responses to logic incompatibility, may not resolve conflict, but rather trigger unpredictable, and perhaps unintended, changes in field-level conditions. In sum, when prior attempts at collaboration result in organizational learning and reframing, as well as escalated contestation, field conditions may be set for subsequent field level changes such as entry by new organizational forms (hybrid organizations in our case).

Our study also enables us to speak to the field-level impacts of logic assimilation, which occurred when SMOs reframed their arguments in terms of economizing in the Lamar decision. While prior studies discuss assimilation as the end of a process of logic conflict (e.g. Arjaliés, 2010; Murray, 2010), our findings suggest that assimilation may represent an important trigger to future field-level change, including logic hybridization. Assimilation of the means of wind energy into the goals of economizing increased the legitimacy of wind energy by reducing its perceived incompatibility with the dominant economizing logic. 
However, because assimilation also kept power in the field concentrated in the hands of the CPUC and the electric utilities, and justified wind energy only in terms of economizing, it left SMOs frustrated, and motivated their movement into direct contestation. The actions that produce assimilation of a subordinate logic (in our case, the justification of a wind project in terms of economizing) provide legitimacy to that logic and its advocates, yet may also leave these advocates dissatisfied and hungry for further change because they have suppressed their own beliefs. While the material means of wind energy were (partially) accepted, the symbolic goals of ecologizing were not acknowledged. Due to their increased legitimacy, advocates in such situations may find that external constituents are more receptive to subordinate logics (Waldron et al., 2013) and are willing to offer greater support, and, depending on the centralization of the field, may find that they can use this support to more aggressively influence their opponents.

Thus, assimilation of a subordinate logic, rather than serving as a burial ground for that logic, may establish fertile ground for social movements to continue to drive change and ultimately hybridize incompatible logics. Surprisingly, the literature in social movements has not considered how assimilation and other developmental changes in field-level logics (Thornton et al., 2002) can be used as opportunities for movement intervention. Instead, most research in this domain addresses how movement activism drives the replacement of institutional logics in a field (e.g., Greenwood, Suddaby, \& Hinings, 2002; Lounsbury, 2002; Rao et al., 2003; Thornton 2001, 2002; Thornton \& Ocasio, 1999). In sum, we posit that logic assimilation can serve as an important intermediary step towards hybridization as it brings legitimacy to a subordinate logic. This is particularly relevant in centralized fields where subordinate logics may need to garner credibility through associations with dominant logics. In addition, under conditions of high logic incompatibility, assimilation may only represent a temporary step as it does not fully resolve 
conflict between logics. Hence we address a gap in existing research, which recognizes that field-level logics evolve over time but does “...not offer an explanation of when one type of change is more likely to prevail than another" (Thornton et al. 2012: 168).

\section{The Role of Hybrid Organizations in Field-Level Logic Hybridization}

Our study has specific implications for understanding the emergence of hybrid organizations and how they contribute to logic hybridization at the field level. We found that the passage of RPS in Colorado opened the door for the growth of organizations, specifically wind developers and clean energy SMOs, that combined economizing and ecologizing logics in their cores and therefore can be viewed as hybrid organizations (Battilana \& Dorado, 2010; $\underline{\text { Besharov }}$ \& Smith, 2014; Pache \& Santos, 2010). Clean energy SMOs then worked to legitimize the emerging hybridized logic for wind energy, while wind developers contributed to logic emergence by demonstrating the economic viability of the wind energy industry.

Our findings suggest that once a new field-level hybridized logic begins to emerge, organizational responses may diversify to include normative and cognitive legitimation of the emerging logic. This role is particularly apt for hybrid organizations because they are embedded in multiple rather than single logics and "...have access to a much broader repertoire of institutionalized templates that they can combine in unique ways" (Pache \& Santos, 2013: 37). This competency is illustrated by clean energy SMOs' utilization of diverse knowledge and capabilities, strategies, and activities that are consistent with the integration of economic and environmental goals (Pacheco et al., 2014).

Prior research indicates that hybrid organizations are "arenas of contradiction" (Pache \& Santos, 2013: 972) in which actors must deal with the tensions arising from the incompatible logics that their organizations embrace. The literature portrays such tensions as originating from decisions regarding legal structure (e.g., for profit vs. nonprofit), financing, and organizational 
cultural challenges (Battilana et al. 2012; Battilana and Lee, 2014). These tensions typically arise when hybrid organizations take on distinct new organizational forms that combine existing forms (Battilana and Lee, 2014). For example, social enterprises blend nonprofit with for-profit models (Moss, Short, Payne, \& Lumpkin, 2011; Miller et al., 2012; Grimes et al., 2013). Hence, these types of organizations may face challenges in finding appropriate means (e.g., legal, organizational structures) that best serve the integration of previously incompatible goals (Smith et al., 2013). These means-goals misalignments may, in turn, prevent hybridized logics from emerging and influencing decision-making within these organizations

In contrast, the hybrid organizations in our case likely experienced less internal identity and cultural struggle because: 1) they adopted well-established organizational forms rather than pioneering new ones, and 2) they were conceived for the express purpose of integrating distinct logics within these forms. While clean energy SMOs may have experienced internal tensions, these tensions were likely ameliorated by the legitimacy of the chosen organizational form (nonprofit model) and their central mission to advocate for the integration of economizing and ecologizing logics. Thus, these hybrid organizations were well positioned to successfully promote logic hybridization within their field.

Consistent with our prior research (Pacheco et al., 2014) we demonstrate that hybrid organizations, such as clean energy SMOs, are more likely to emerge under specific field conditions, and that the emergence of these organizations then recursively influences the field. However, we extend prior findings by demonstrating the important role that hybrid organizations play in not only in altering the structure and material forms of a field (e.g., governance, policies, incentives), but also in fostering the hybridization of logics more broadly.

Our findings suggest that hybrid organizations may be far from homogenous in the tensions they experience, and the capabilities they hold (Besharov \& Smith, 2014). We observed 
key differences in these aspects between the clean energy SMOs examined in this study and the social enterprises that abound in the hybrid organizations literature. These two types of hybrid organizations likely also have different levels of influence on field-level processes of logic hybridization. This does not imply that social enterprises cannot espouse or advocate for hybridized logics, but rather, that their ability to do so may be influenced by their internal dynamics. Our case primarily describes how external conditions can determine the success of hybrid organizations in contributing to field level hybridization processes. However, future research is necessary to understand how the internal environment and the tensions inherent within hybrid organizations may affect their ability to influence logic hybridization at the field level. We suspect that future studies will uncover significant parallels between the organizational- level struggles described in the prior literature, and the field-level processes of change detailed in this study.

\section{Boundary Conditions and Limitations}

We expect that the theoretical insights from this study may be applicable in organizational fields similar to the one we studied; that is, fields characterized by initial conditions of high centralization and dominance of a single logic. Contrary to prior work on compromise and logic assimilation, we find that attempts by less powerful actors to gain voice did not resolve incompatibility, but rather motivated eventual contestation. In a less centralized field, we would expect that proponents of a subordinate logic might not be sufficiently motivated to alter field structure, and (albeit unintentionally) create opportunity for hybrid organizations. As our case study shows, altering the structure of fields is a long and difficult process that occurred only when advocates were dissatisfied by compromise and assimilation. In addition, we believe that our theoretical contribution is more applicable to fields that, like the one we studied, are characterized by a high degree of perceived logic incompatibility. Fields with more 
compatible logics may not require hybridization, as the goals of multiple logics can be accommodated. Without high incompatibility, we would expect that assimilation or blending would be the expected outcome of logic plurality. However, in fields with persistent logic incompatibility, we note that assimilation may be only a precursor to logic hybridization, rather than a sustainable solution.

Finally, we believe that our refined definition of hybridized logics could be applicable to other fields where practices are reconstructed to support previously incompatible goals. Future studies could help to clarify how and when logic hybridization occurs, as compared to a narrower blending of elements from diverse logics. Such studies could also shed light on the conditions under which developmental changes such as assimilation are needed as intermediary steps to eventual hybridization. It is likely that the dynamics (e.g., competition, cooperation) between organizations in a field and other exogenous shocks, such as technological innovations, also impact how developmental and transformational changes in institutional logics take place. Potential applications include the current health care debate in the United States and the incompatibility of market and social welfare logics in the international debate on climate change (Ansari et al., 2013; Hiatt, Grandy, \& Lee, 2015).

A potential limitation of our study is the inherent retrospective bias of interviews regarding past events. However, as detailed in Table 1 and Table 2, all of our themes were triangulated from multiple archival sources as well as interviews. Because the goal of our case study was to attain a rich, detailed understanding of the processes that unfolded within the wind energy field in Colorado, we could not assess the role of external trends and forces that may have impacted the relationships we explored. However, we gain comfort from prior empirical research that has considered the influence of national-level economic and social factors, such as pricing variations in wind power and the visibility of environmental issues. These studies have found 
that controlling for these macro-level conditions, the actors in our case, environmental and clean

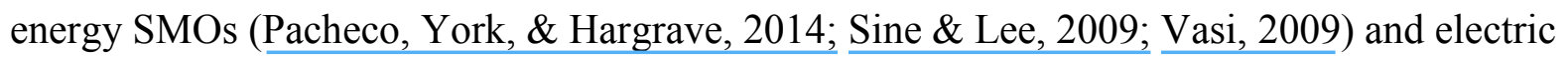
utilities (Pacheco and Dean, 2014), have played critical roles in driving the direction of the wind energy industry.

\section{Conclusion}

With a focus on how actors respond to logic incompatibility, this study clarified how and why field-level logic hybridization occurs. Our findings suggest that the process of establishing practices, technologies, and organizations that provision both economic and environmental benefits is a complex one involving the participation of a variety of actors, each adapting their strategies as they learn and as field conditions change. With increasing calls for reforming economic systems and the rise of hybrid organizations, exploring and understanding these processes should be an integral part of organizational research. This study provides an early step towards understanding the complex interplay of field logics, structure, and organizational actions through which logic hybridization occurs. 


\section{REFERENCES}

Aldrich, H. E. \& Fiol, C. M. 1994. Fools rush in? The institutional context of industry creation. Academy of Management Review, 19(4): 645626 pages.

Ansari, S., Wijen, F., \& Gray, B. 2013. Constructing a Climate Change Logic: An Institutional Perspective on the 'Tragedy of the Commons'. Organization Science, 24(4): 1014-1040.

Arjaliès, D. 2010. A social movement perspective on finance: How socially responsible investment mattered. Journal of Business Ethics, 92: 57-78.

Ashforth, B. \& Reingen, P.H. 2014. Functions of dysfunction: Managing the dynamics of an organizational duality in a natural food cooperative. Administrative Science Quarterly, Forthcoming.

Barley, S. R. \& Tolbert, P. S. 1997. Institutionalization and structuration: Studying the links between action and institution. Organization Studies, v18(n1): p93(25).

Battilana, J., Leca, B., \& Boxenbaum, E. 2009. How actors change institutions: Towards a theory of institutional entrepreneurship. The Academy of Management Annals, 3(1): 65-107.

Battilana, J. \& Dorado, S. 2010. Building sustainable hybrid Ooganizations: The case of commercial microfinance organizations. Academy of Management Journal, 53(6): 1419-1440.

Battiliana, J., Lee, M., Walker, J., \& Dorsey, C. 2012. In search of the hybrid ideal. Stanford Social Innovation Review, 10(3): 50-55.

Battilana, J. \& Lee, M. 2014. Advancing research on hybrid organizing-Insights from the study of social enterprises. The Academy of Management Annals, 8(1): 397-441.

Benford, R. D. \& Snow, D. A. 2000. Framing processes and social movements: An overview and assessment, Annual Review of Sociology, Vol. 26: 611-639: Annual Reviews.

Besharov, M.L., \& Smith. W.K. 2014. Multiple institutional logics in organizations: Explaining their varied nature and implications. Academy of Management Review, 39. 364-381.

Bolinger, M. 2010. Revealing the hidden value that the federal investment tax credit and treasury cash grant provide to community wind projects. Lawrence Berkeley National Laboratory. January. Available at http://eetd.lbl.gov/ea/emp

Booth, M. 2001. Energy solution: Blowin' in the wind? Xcel seems reluctant in invest in cost-competitive power, The Denver Post, 2nd Edition ed.: A-01. Denver, CO: Media NewsGroup Inc.

Brandemuehl, M. J. 2005. A sustainable energy future possible, The Denver Post: E-04. Denver, CO: MediaNews Group Inc.

Bromley, P., \& Powell, W.W. 2012. From smoke and mirrors to walking the talk: Decoupling in the contemporary world. Academy of Management Annals, 6: 483-530.

CCEC (Colorado Clean Energy Cluster), 2012. http://www.coloradocleanenergy.com/home. Accessed February 15, 2012

CORE \& Levenson, J. 2009. Colorado Cleantech Cluster Analysis 2009: CORE. 
Cox, C. 2006. Making renewable energy a reality, The Denver Post, Final Edition ed. Denver, CO: MediaNews Group Inc.

CPUC. 2001a. DECISION NO.CO1-295. Denver, CO: Colorado Public Utilities Commission.

CPUC. 2001b. PUC Approves Xcel resource plan with addition of wind project, Press Release. Denver, CO: State of Colorado Public Utilities Commission.

CPUC. 2002. Decision No. C02-793. Denver, Colorado: Colorado Public Utiliities Commission.

CPUC. 2007. Testimony of Ronald J. Binz, Chairman, Colorado Public Utilities Commission: Renewable Energy: Complementary Policies for Climate Legislation, Press Release. Denver, CO: State of Colorado Public Utlities Commission.

CPUC. 2008a. DOCKET NO. 07A-447E. Denver, CO: Colorado Public Utilities Commission.

CPUC. 2008b. Decision No. C08-0929. In C. P. U. Commission (Ed.). Denver, CO: Colorado Public Utilities Commission.

Dacin, M. T., Dacin, P. A., \& Tracey, P. 2011. Social entrepreneurship: A critique and future directions. Organization Science, 22(5): 1203-1213.

Delbridge, R., \& Edwards, T. 2013. Inhabiting institutions: Critical realist refinements to understanding institutional complexity and change. Organization Studies, 34: 927-947.

DiMaggio, P. 1988. Interest and agency in institutional theory. In L. Zucker (Ed.), Institutional Patterns and Organizations: 3-22. Cambridge, MA: Ballinger.

DiMaggio, P. J. \& Powell, W. W. 1983. The Iron Cage Revisited: Institutional Isomorphism and Collective Rationality in Organizational Fields. American Sociological Review, 48(2): 147-160.

DSIRE. 2010. Database of State Incentives for Renewable Energy and Efficiency

Dunn, M. B. \& Jones, C. 2010. Institutional logics and institutional pluralism: The contestation of care and science logics in medical education, 1967-2005. Administrative Science Quarterly, 55(1): 114-149.

Eisenhardt, K. \& Graebner, M. 2007. Theory building from cases: Opportunities and challenges.

Academy of Management Journal, 50(1): 25-32.

Elsbach, K. D. \& Sutton, R. I. 1992. Acquiring organizational legitimacy through illegitimate actions: A marriage of institutional and impression management theories. Academy of Management Journal, 35(4): 699-738.

Ewegen, B. 1999. Buying Power: Idealogical sparks fly over electrical deregulation, The Denver Post Denver, CO. MediaNews Group Inc.

Fligstein, N. 1996. Markets as politics: A political-cultural approach to market institutions. American Sociological Review, 61: 228-244.

Friedland, R. 2002. Money, sex, and god: The erotic logic of religious nationalism. Sociological Theory, 20(3): 381-425. 
Frederick, W. C. 1995. Values, nature, and culture in the American corporation. New York: Oxford University Press.

Friedland, R. \& Alford, R. R. 1991. Bringing society back in: Symbols, practices and institutional contradictions. In W. W. Powell \& P. J. Dimaggio (Eds.), The New Institutionalism in Organizational Analysis: 232-263. Chicago, IL: University of Chicago Press.

Gioia, D. A., Corley, K. G., \& Hamilton, A. L. 2013. Seeking qualitative rigor in inductive research: Notes on the Gioia methodology. Organizational Research Methods, 16(1): 15-31.

Gladwin, T. N., Kennelly, J. J., \& Krause, T.-S. 1995. Shifting paradigms for sustainable development: Implications for management theory and research. Academy of Management Review, 20(4): 874-907.

Glaser, B. G. \& Strauss, A. L. 1967. The discovery of grounded theory: Strategies for qualitative research: Chicago, IL: Aldine Transaction.

Glynn, M. A. \& Lounsbury, M. 2005. From the critics' corner: Logic blending, discursive Change and authenticity in a cultural production system. Journal of Management Studies, 42(5): 1031-1055.

Goffman, E. 1974. Frame analysis: An essay on the organization of experience. London, UK: Harper \& Row.

Golden-Biddle, K. \& Locke, K. 2007. Composing qualitative research. Thousand Oaks, Calif.: Sage.

Goodrick, E. \& Reay, T. 2011. Constellations of institutional logics: Changes in the professional work of pharmacists. Work and Occupations, 38(3): 372-416.

Greenwood, R., Díaz, A. M., Li, S. X., \& Lorente, J. C. 2010. The multiplicity of institutional logics and the heterogeneity of organizational responses. Organization Science, 21(2): 521-539.

Greenwood, R., Raynard, M., Kodeih, F., Micelotta, E. R., \& Lounsbury, M. 2011. Institutional complexity and organizational responses. The Academy of Management Annals, 5(1): 317-371.

Grimes, M. G., McMullen, J. S., Vogus, T. J., \& Miller, T. L. 2013. Studying the origins of social entrepreneurship: Compassion and the role of embedded agency. Academy of management review, 38(3): 460-463.

Haigh, N. \& Hoffman, A. J. 2012. Hybrid organizations. Organizational Dynamics, 41(2): 126.

Hargrave, T. J. \& van de Ven, A. H. 2006. A collective action model of institutional innovation. Academy of Management Review, 31(4): 864-888.

Hiatt, Shon and Grandy, Jake and Lee, Brandon H., 2015. Organizational Responses to Public and Private Politics: An Analysis of Climate Change Activists and U.S. Oil and Gas Firms (May 2, 2015). Available at SSRN: http://ssrn.com/abstract=2601797

Hiatt, S. R. \& Sangchan, P. 2013. Lords of the harvest:: third-party influence and regulatory approval of genetically modified organisms. Academy of Management Journal, 56(4): 923-944.

Hiatt, S., Sine, W., \& Tolbert, P. S. 2009. From Pabst to Pepsi: The Deinstitutionalization of Social Practices and the Creation of Entrepreneurial Opportunities. Administrative Science Quarterly, 54(4): 635-667. 
Hoffman, A. J. 1999. Institutional evolution and change: Environmentalism and the U.S. chemical industry. The Academy of Management Journal, 42(4): 351-371.

Hoffman, A.J. 2011. Talking past each other? Cultural framing of skeptical and convinced logics in the climate change debate. Organization \& Environment, 24: 3- 33.

Hoffman, A. J., Gillespie, J. J., Moore, D. A., Wade-Benzoni, K. A., Thompson, L. L., \& Bazerman, M. H. 1999. A mixed-motive perspective on the economics versus environment debate. American Behavioral Scientist, 42(8): 1254-1276.

Hoffman, A. J., Badiane, K. K., \& Haigh, N. 2012. Hybrid organizations as agents of positive social change: Bridging the for-profit \& non-profit divide: Routledge, Taylor and Francis Group.

Holm, P. 1995. The dynamics of institutionalization: Transformation processes in Norwegian fisheries. Administrative Science Quarterly, 40(3): 398-422.

IPCC. 2011. The IPCC Special Report on Renewable Energy Sources and Climate Change Mitigation: New York, NY: United Nations Environment Programme.

IPCC. 2013. Summary for Policymakers. In: Climate Change 2013: The Physical Science Basis. In T. F. Stocker \& D. Qin (Eds.). Switzerland: IPCC.

IPCC. 2014. Climate Change 2014: Impacts, Adaptation and Vulnerability. In W. G. II (Ed.), Fifth Assessment Report (AR5). Geneva, Switzerland: Intergovernmental Panel on Climate Change.

IREA. 2004. Does the wind really blow for free?, Watts $\&$ Volts Sedalia, CO: Intermountain Rural Electric Association.

Komor, P. 2006. Wind power in Colorado: Small steps towards sustainability. Sustainable Energy and the States. London, UK: McFarland \& Company Inc.

Langley, A., Smallman, C., Tsoukas, H., \& Van de Ven, A. H. 2013. Process studies of change in organization and management: unveiling temporality, activity, and flow. Academy of Management Journal, 56(1): 1-13.

Lawrence, T.B. 2008. Power, institutions, and organizations. In Greenwood, R., Oliver, C., Suddaby, R., \& Sahlin-Andersson, K. (Ed.). The Sage Handbook of Organizational institutionalism: 170-197.

London, UK: Sage.

Lawrence, T., Suddaby, R., \& Leca, B. 2011. Institutional work: Refocusing institutional studies of organization. Journal of Management Inquiry, 20(1): 52-58.

Lawrence, T. B. \& Suddaby, R. 2006. Institutions and institutional work. The Sage Handbook of Organization Studies: 215-254.

Leblebic, H., Salancik, G. R., Copay, A., \& King, T. 1991. Institutional change and the transformation of interorganizational fields: an organizational history of the US radio broadcasting industry. Administrative Science Quarterly, 36(3). 
Lee, M.P, \& Lounsbury, M. 2015. Filtering Institutional Logics: Community Logic Variation and Differential Responses to the Institutional Complexity of Toxic Waste. Organization Science, Articles in Advance 11 Feb 2015. http://dx.doi.org/10.1287/orsc.2014.0959

Lehr, R. L., Nielsen, J., Andrews, S., \& Milligan, M. 2001. Colorado Public Utility Commission's Xcel wind decision, $\boldsymbol{A} \boldsymbol{W E A}$ 's Windpower 2001 Conference. Washington, D.C.: National Renewable Energy Labratory.

Leib, J. 1998. PSC aims to boost power Utility's plan includes renewable sources, The Denver Post: C01. Denver, CO: MediaNews Group Inc.

Lepoutre, J.M.W.N., \& Valente, M. 2012. Fools breaking out: The role of symbolic and material immunity in explaining institutional nonconformity. Academy of Management Journal, 55: 285-313.

Levy, D. \& Scully, M. 2007. The institutional entrepreneur as modern prince: The strategic face of power in contested fields. Organization Studies, 28(7): 971-991.

Locke, K. 2001. Grounded theory in management research. London, UK; Thousand Oaks, Calif.: Sage Publications.

Lounsbury, M., Ventresca, M., \& Hirsch, P. M. 2003. Social movements, field frames and industry emergence: a cultural-political perspective on US recycling. Socio-Economic Review, 1(1): 71-104.

Lounsbury, M. \& Crumley, E. T. 2007. New practice creation: An institutional perspective on innovation. Organization Studies, 28(7): 993-1012.

Marquis, C. \& Lounsbury, M. 2007. Vive la resistance: Competing logics and the consolidation of US community banking. Academy of Management Journal, 50(4): 799-820.

Mars, M. M. \& Lounsbury, M. 2009. Raging against or with the private marketplace? Logic hybridity and eco-entrepreneurship. Journal of Management Inquiry, 18(1): 4-13.

Mayer, R., Blank, E., \& Swezey, B. 1999. The grassroots are greener: A community-based approach to marketing green power, Renewable Energy Policy Project Research Report. Washington, DC:

Renewable Energy Policy Project.

Mayer, Blank, Udall, and Nelson. 1997. Promoting renewable energy in a market Environment: A community-based approach for aggregateing green demand. Land and Water Fund of the Rockies/U.S. Department of Energy Report. Boulder, CO: Land and Water Fund of the Rockies.

McAdam, D., McCarthy, J. D., \& Zald, M. N. 1996. Introduction: Opportunities, mobilizing structures, and framing processes--toward a synthetic, comparative perspective on social movements. In D. McAdam, J. D. McCarthy, \& M. N. Zald (Eds.), Comparative perspectives on social movements: Political opportunities, mobilizing structures and cultural framings: 1-20. New York: Cambridge University Press.

McAdam, D., Tarrow, S., \& Tilly C. 2001. Dynamics of contention. New York: Cambridge University Press.

McCarthy, J. D. \& Zald, M. N. 1973. The trend of social Movements in America: Professionalization and resource mobilization. Morristown, NJ: General Learning Press. 
McKinnon, J.T. \& Hart, G. 2008. Guest Commentary: Our new energy economy. The Denver Post Denver, CO. MediaNews Group Inc.

Meyer, J., Scott, W. R., \& Strang, D. 1987. Centralization, fragmentation, and school district complexity. Administrative Science Quarterly: 186-201.

Meyer, J. W. \& Rowan, B. 1977. Institutionalized organizations: Formal structure as myth and ceremony. American Journal of Sociology, 83(2): 340.

Meyer, R. E. \& Hammerschmid, G. 2006. Changing institutional logics and executive identities A managerial challenge to public administration in Austria. American Behavioral Scientist, 49(7): 10001014.

Murray, F. 2010. The oncomouse that roared: Hybrid exchange strategies as a source of distinction at the boundary of overlapping institutions. American Journal of Sociology, 116(2): 341-388.

Miller, T., Grimes, M., McMullen, J., \& Vogus, T. 2012. Venturing for others with heart and head: How compassion encourages social entrepreneurship. Academy of Management Review, 38(3): 460-463.

Moss, T. W., Short, J. C., Payne, G. T., \& Lumpkin, G. T. 2011. Dual Identities in Social Ventures: An Exploratory Study. Entrepreneurship Theory and Practice, 35(4): 805-830.

Nigam, A. \& Ocasio, W. 2010. Event attention, environmental sensemaking, and change in institutional logics: An inductive analysis of the effects of public attention to Clinton's health care reform initiative. Organization Science, 21(4): 823-841.

Office of the Governor of Colorado. 2008. Gov. Ritter names Matt Baker to Public Utilities Commission. Denver, CO: Office of the Governor of Colorado.

Office of the Governor of Colorado. 2010. Colorado's new energy economy. Denver, CO: Office of the Governor of Colorado.

Olinger, D. 2004. Statewide ballot issues Amendment 3710 percent by 2015: Energy initiative would force Colo. to reap renewables, The Denver Post. Denver, CO: Media News Group Inc.

Oliver, C. 1991. Strategic responses to institutional processes. Academy of Management Review: 145179.

Pache, A.-C. \& Santos, F. 2013. Inside the hybrid organization: Selective coupling as a response to competing institutional logics. Academy of Management Journal, 56(4): 972-1001.

Pache, A. C. \& Santos, F. 2010. When worlds collide: The internal dynamics of organizational responses to conflicting institutional demands. Academy of Management Review (AMR), 35(3): 455-476.

Pacheco, D. \& Dean, T.J. 2014. Firm Responses to social movement pressures: A competitive dynamics perspective. Strategic Management Journal, Forthcoming.

Pacheco, D. F., York, J. G., \& Hargrave, T. J. 2014. The Coevolution of Industries, Social Movements, and Institutions: Wind Power in the United States. Organization Science, 25(6): 1609-1632.

Partnership for Sustainability, 2012. http://www.partnershipforsustainability.org/whoweare. Accessed February 15, 2012 
Plowman, D. A., Baker, L. T., Beck, T. E., Kulkarni, M., Solansky, S. T., \& Travis, D. V. 2007. Radical change accidentally: The emergence and amplification of small change. Academy of Management Journal, 50(3): 515-543.

Raabe, S. 2001. Xcel, wind-power group hope to sway PUC with energy plans, Denver Post, 1st Edition ed.: C-01. Denver, CO: Denver Newspaper Group.

Raabe, S. 2003. Colorado gets and F on renewable energy: Group criticizes state policies amid 'green power' success, The Denver Post: C-01. Denver, CO: MediaNews Group Inc.

Raabe, S. \& Bunch, J. 2003. Project a winner, advocates say, The Denver Post: K-01. Denver, CO: MediaNews Group Inc.

Raabe, S. 2006. Steady wind means pricier power: Customers lose cost advantage of green source Natural gas and coal got cheaper again. Xcel now wants Windsource to be always more expensive., The Denver Post: C-01. Denver, CO: MediaNews Group Inc.

Raabe, S. 2007. Bill gains to double renewable energy In line with Gov. Ritter's goals, a House panel passes a measure raising the state's mandatory standard to 20 percent by 2020, The Denver Post Denver, CO. MediaNews Group Inc.

Reay, T. \& Hinings, C. R. B. 2005. The recomposition of an organizational field: Health care in Alberta. Organization Studies, 26(3): 351-384.

Reay, T. \& Hinings, C. R. 2009. Managing the rivalry of competing institutional logics. Organization Studies, 30(6): 629-652.

Sanderson, S. A. 2004. Energy market created by fiat?, The Denver Post: E-04. Denver, CO: MediaNews Group Inc.

Sauder, M., \& Espeland, W.N. 2009. The discipline of rankings: Tight coupling and organizational change. American Sociological Review. 74: 63-82.

Schneiberg, M. \& Lounsbury, M. 2008. Social movements and institutional analysis. Handbook of Organizational Institutionalism: 650-672.

Scott, W. R. \& Meyer, J. W. 1991. The organization of societal sectors: Popositions and early evidence. In W. W. Powell \& P. J. DiMaggio (Eds.), The new institutionalism in organizational analysis: 108-142. Chicago, IL: University of Chicago Press.

Scott, W. R. 1995. Institutions and Organizations. Thousand Oaks, CA: Sage Publications, Inc.

Scott, W. R. 2008. Lords of the dance: Professionals as institutional agents. Organization Studies, 29(2): 219-238.

Seo, M. G. \& Creed, W. E. D. 2002. Institutional contradictions, praxis, and institutional change: A dialectical perspective. Academy of Management Review, 27(2): 222-247.

Shipilov, A.V., Greve, H.R., \& Rowley, T.J. 2010. When do interlocks matter? Institutional logics and the diffusion of multiple corporate governance practices. Academy of Management Journal, 53: 846864. 
Siggelkow, N. 2007. Persuasion with case studies. Academy of Management Journal, 50(1): 20-24.

Sine, W. D. \& Lee, B. 2009. Tilting at windmills? The environmental movement and the emergence of the U.S. Wind Energy sector. Administrative Science Quarterly, 54: 123-155.

Smets, M., Morris, T., \& Greenwood, R. 2012. From practice to field: A multilevel model of practicedriven institutional change. Academy of Management Journal, 55(4): 877-904.

Smith, W.K., Gonin, M., \& Besharov, M.L. 2013. Managing social-business tensions: A review and research agenda for social enterprise. Business Ethics Quarterly, 23, 407-442.

Staggenborg, S. 1988. The consequences of professionalization and formalization in the pro-choice movement. American Sociological Review: 585-605.

Stinchcombe, A. L. 1965. Social Structure and Organizations. Handbook of Organizations: 142-193. Chicago, IL: Rand McNally.

Strauss, A. \& Corbin, J. 1994. Grounded theory methodology. Handbook of qualitative research: 273285. Thosand Oaks, CA: Sage.

Thornton, P. H. \& Ocasio, W. 1999. Institutional logics and the historical contingency of power in organizations: Executive succession in the higher education publishing industry, 1958-1990 1. American Journal of Sociology, 105(3): 801-843.

Thornton, P. H. \& Ocasio, W. 2008. Institutional logics. In R. Greenwood (Ed.), The SAGE handbook of organizational institutionalism. Los Angeles, Calif.: Sage.

Thornton, P. H., Ocasio, W., \& Lounsbury, M. 2012. The institutional logics perspective: A new approach to culture, structure, and process. Oxford, UK: Oxford University Press.

Tracey, P., Phillips, N., \& Jarvis, O. 2011. Bridging institutional entrepreneurship and the creation of new organizational forms: A Multilevel Model. Organization Science, 22(1): 60-80.

van de Ven, A. H. v. d. \& Poole, M. S. 1995. Explaining development and change in organizations. The Academy of Management Review, 20(3): 510-540.

Vasi, I. B. 2009. Social movements and industry development: the environmental movement's impact on the wind energy industry. Mobilization: An International Journal, 14(3): 315-336.

Wade-Benzoni, K. A., Hoffman, A. J., Thompson, L. L., Don, A. M., Gillespie, J. J., \& Bazerman, M. H. 2002. Barriers to resolution in ideologically based negotiations: The role of values and institutions.

Academy of Management Review, 27(1): 41-57.

Wattenburg, D. 1998. Coal is still king, The Denver Post: B-07. Denver, CO: MediaNews Group Inc.

Western Resource Advocates; http://www.westernresourceadvocates.org/about/; 4/26/2011, 2011.

Westphal, J.D., \& Zajac, E.J. 1994. Substance and symbolism in CEOs' long-term incentive plans. Administrative Science Quarterly, 39: 367-390.

Wiser, R. \& Bolinger, M. 2012. Wind Technologies Market Report. U.S. Department of Energy. Oak Ridge, TN: U.S. Departmetn of Energy. 
Wooten, M. \& Hoffman, A. J. 2008. Organizational Fields. The Sage Handbook of Organizational Institutionalism: 130-147.

Waldron, T., Navis, C., \& Fisher, G. 2013. Explaining Differences in Firms Responses to Activism Academy of Management Review, 38(3): 397-417.

Waldron, T. L., Fisher, G., \& Navis, C. 2015. Institutional entrepreneurs' social mobility in organizational fields. Journal of Business Venturing, 30(1): 131-149.

Wry, T., Lounsbury, M., \& Jennings, P. D. 2014. Hybrid Vigor: Securing Venture Capital by Spaning Categories in Nanotechnology. Academy of Management Journal, 57(5): 1309-1333.

Wry, T., Cobb, J. A., \& Aldrich, H. E. 2013. More than a metaphor: Assessing the historical legacy of resource dependence and its contemporary promise as a theory of environmental complexity. Academy of Management Annals, 7(1), 441-488.

Xcel Energy. 2001. Denver: Xcel Energy expands Windsource. http://www.xcelenergy.com.

Xcel Energy. 2004. Wayne Brunetti remarks - World Energy Congress. http://www.xcelenergy.com.

Xcel Energy. 2007. A Report on the Economic/Enviornmental/Social Impacts of Xcel Energy. http://www.xcelenergy.com.

Xcel Energy. 2008. Responsible by Nature: 2008 Corporate Sustainability Report.

http://www.xcelenergy.com.

Yin, R. K. 2002. Case study research: Design and methods (3rd ed.). Thousand Oaks: SAGE Publications Incorporated.

Zajac, E.J., \& Westphal, J.D. 1995. Accounting for the explanations of CEO compensation: Substance and symbolism. Administrative Science Quarterly, 40(2): 283-308.

Zietsma, C. \& Lawrence, T. B. 2010. Institutional work in the transformation of an organizational field: The interplay of boundary work and practice work. Administrative Science Quarterly, 55(2): 189-221.

Zimmerman, M. A. \& Zeitz, G. J. 2002. Beyond survival: Achieving new venture growth by building legitimacy Academy of Management Review, 27(3): 414-431.

Zott, C. \& Huy, Q. N. 2007. How entrepreneurs use symboic management to acquire resources. Administrative Science Quarterly, 52(1): 70-105. 
TABLE 1

Description of Data

\begin{tabular}{|c|c|c|}
\hline Data Types and Dates & $\begin{array}{l}\text { Amount and } \\
\text { Location }\end{array}$ & Use in Analysis \\
\hline \multicolumn{3}{|l|}{$\underline{\text { Primary Data }}$} \\
\hline $\begin{array}{l}\text { Semi-structured interviews } \\
34 \text { interviews lasting between } \\
60 \text { minutes and } 3 \text { hours } \\
\text { (July } 28,2010 \text { - April } 18 \text {, } \\
\text { 2014) }\end{array}$ & $\begin{array}{l}379 \text { pages } \\
\text { (transcriptions } \\
\text { from digital } \\
\text { recording) }\end{array}$ & $\begin{array}{l}\text { Insight into the beliefs, motivations, and strategies } \\
\text { of actors regarding logic incompatibility } \\
\text { surrounding wind energy. }\end{array}$ \\
\hline $\begin{array}{l}\text { Naturalistic observation } \\
\text { National Renewable Energy } \\
\text { Lab Tour (September 3, } \\
\text { 2010; December 7, 2012; } \\
\text { November 20, 2013) }\end{array}$ & $\begin{array}{l}3 \text { tours (Golden, } \\
\quad \mathrm{CO})\end{array}$ & $\begin{array}{l}\text { Participant observation and informal discussion } \\
\text { building insight into how wind energy research } \\
\text { and policy is articulated to the public in } \\
\text { Colorado. }\end{array}$ \\
\hline $\begin{array}{l}\text { National Wind Technology } \\
\text { Center (August 2, 2010) }\end{array}$ & $\begin{array}{l}1 \text { visit (near } \\
\text { Boulder, } \mathrm{CO} \text { ) }\end{array}$ & $\begin{array}{l}\text { Informal discussion building insight into policy and } \\
\text { technology barriers to wind energy adoption. }\end{array}$ \\
\hline $\begin{array}{l}\text { Visits to Xcel Energy (January } \\
\text { 24; April 8, 2014) }\end{array}$ & $\begin{array}{l}2 \text { visits (Denver, } \\
\text { CO) }\end{array}$ & $\begin{array}{l}\text { Presentation of research for feedback from utility } \\
\text { executives building insight into past and current } \\
\text { views of wind energy, accuracy of findings. }\end{array}$ \\
\hline $\begin{array}{l}\text { Attendance of CORE } \\
\text { Sustainable Opportunities } \\
\text { Summit (February 27, } \\
\text { 2008; March 17, 2009; } \\
\text { March 2, 2010) }\end{array}$ & $\begin{array}{l}3 \text { annual meetings } \\
\text { (Denver, CO) }\end{array}$ & $\begin{array}{l}\text { Participant observation building understanding of } \\
\text { usage of economizing, ecologizing, and hybrid } \\
\text { arguments. }\end{array}$ \\
\hline$\underline{\text { Secondary Data }}$ & & \\
\hline $\begin{array}{l}\text { Newspaper articles } \\
\text { All articles concerning wind } \\
\text { energy in The Denver Post } \\
\text { (October 22, 1996- } \\
\text { January 9, 2009) }\end{array}$ & $\begin{array}{l}546 \text { articles } \\
\text { (accessed via } \\
\text { LexisNexis) }\end{array}$ & $\begin{array}{l}\text { Coded for frequency of economizing, ecologizing, } \\
\text { and hybrid logic usage and field-level } \\
\text { interpretation of wind energy over time. } \\
\text { Triangulations of informant reports. }\end{array}$ \\
\hline $\begin{array}{l}\text { CPUC press releases } \\
\text { All Colorado Public Utilities } \\
\text { Commission press releases } \\
\text { on wind energy (October } \\
18,2000 \text { - August } 30, \\
2009)\end{array}$ & $\begin{array}{l}58 \text { pages } \\
\text { (accessed } \\
\text { online through } \\
\text { CPUC } \\
\text { archive) }\end{array}$ & $\begin{array}{l}\text { Coded for relationship between logics and field } \\
\text { centralization. }\end{array}$ \\
\hline $\begin{array}{l}\text { Archival websites } \\
\text { All Colorado utility home page } \\
\text { mentions of wind energy } \\
\text { (July 1, 1999- October } 29 \text {, } \\
\text { 2009) }\end{array}$ & $\begin{array}{l}31 \text { press releases } \\
\text { (accessed } \\
\text { online } \\
\text { archive.org) }\end{array}$ & $\begin{array}{l}\text { Coded for utility perspective on wind energy, } \\
\text { arguments against Amendment } 37 .\end{array}$ \\
\hline
\end{tabular}


TABLE 1

Description of Data (cont.)

\begin{tabular}{|c|c|c|}
\hline Data Types and Dates & $\begin{array}{c}\text { Amount and } \\
\text { Location }\end{array}$ & Use in Analysis \\
\hline \multicolumn{3}{|l|}{ Secondary Data (cont.) } \\
\hline $\begin{array}{l}\text { Resource plans } \\
\text { All available Colorado } \\
\text { Utilities resource plans } \\
\text { (December 12, 2002- } \\
\quad \text { February } 8,2008))\end{array}$ & $\begin{array}{l}10 \text { documents, } \\
364 \text { pages } \\
\text { (accessed } \\
\text { online through } \\
\text { CPUC } \\
\text { archive) }\end{array}$ & $\begin{array}{l}\text { Insight into utilities' plans regarding current and } \\
\text { future adoption of wind energy. }\end{array}$ \\
\hline \multicolumn{3}{|l|}{$\begin{array}{l}\text { Archival documents and } \\
\text { reports }\end{array}$} \\
\hline $\begin{array}{l}\text { A variety of reports and } \\
\text { archival documents } \\
\text { provided or authored by: }\end{array}$ & & $\begin{array}{l}\text { Coded for insight into perspective of various actors, } \\
\text { arguments, and strategies utilized to promote } \\
\text { their views. }\end{array}$ \\
\hline Researchers & 4 docs/136 pages & \\
\hline Clean Energy SMOs & 4 docs $/ 117$ pages & \\
\hline Environmental SMOs & 6 docs $/ 126$ pages & \\
\hline Government Agencies & 2 docs $/ 38$ pages & \\
\hline CPUC & 2 docs $/ 35$ pages & \\
\hline $\begin{array}{l}\text { Xcel Energy } \\
\text { (May } 1997 \text { - November 2009) }\end{array}$ & 10 docs $/ 153$ pages & \\
\hline Archival video footage & & \\
\hline $\begin{array}{l}\text { Video footage related to } \\
\text { coverage and promotion of } \\
\text { the Windsource program } \\
\text { (May } 1999 \text { - August, } \\
\text { 2003) }\end{array}$ & $\begin{array}{l}12 \text { videos / } 32 \\
\text { minutes } \\
\text { (provided by } \\
\text { Xcel Energy) }\end{array}$ & $\begin{array}{l}\text { Insight into public promotion and perception of } \\
\text { Windsource program and wind energy. }\end{array}$ \\
\hline
\end{tabular}


TABLE 2

Data Structure

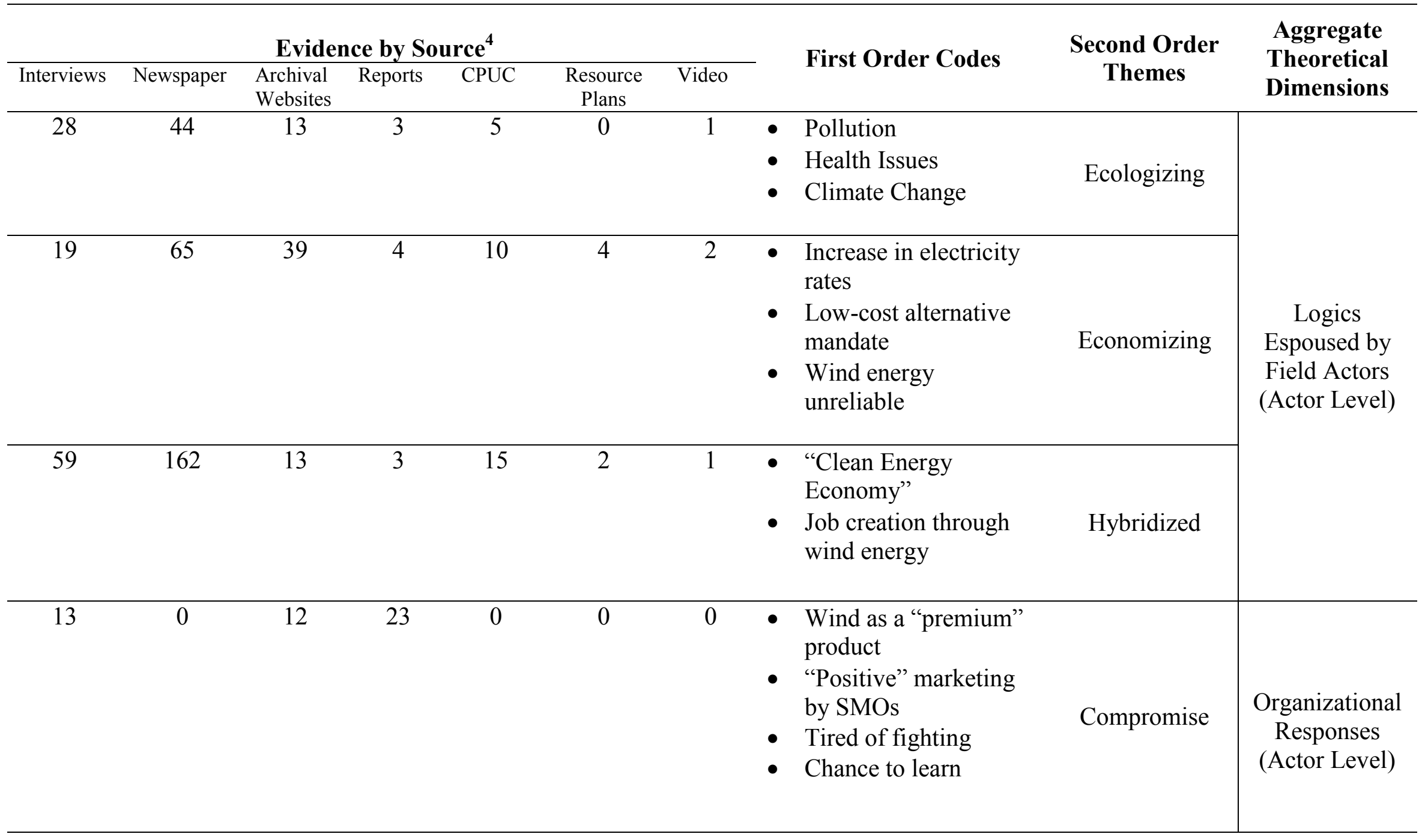

\footnotetext{
${ }^{4}$ Each number is the count of passages of text coded by source for a given theme.
} 
TABLE 2

Data Structure (cont.)

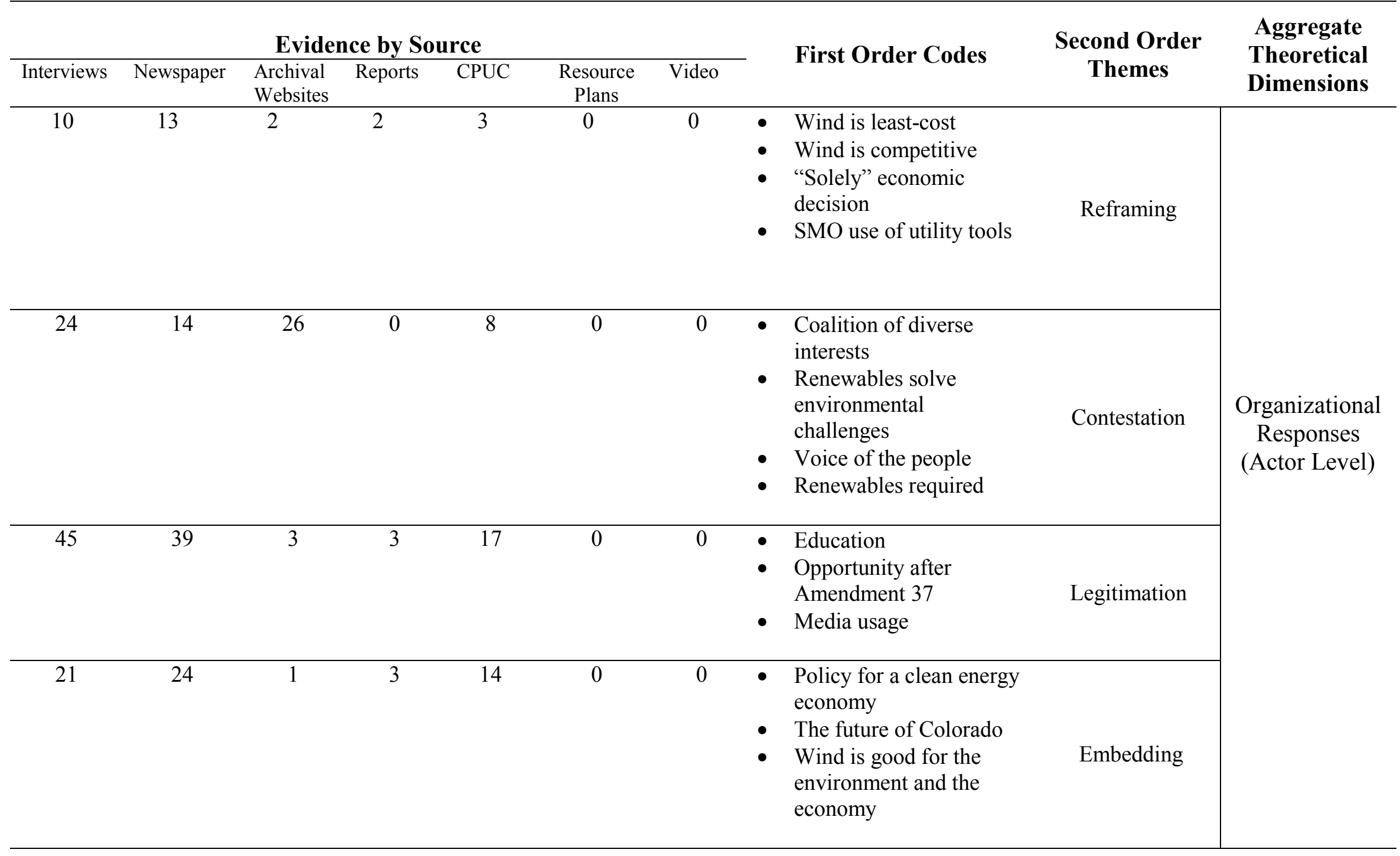


TABLE 2

Data Structure (cont.)

\begin{tabular}{|c|c|c|c|c|c|c|c|c|c|}
\hline \multicolumn{7}{|c|}{ Evidence by Source } & \multirow{2}{*}{ First Order Codes } & \multirow{2}{*}{$\begin{array}{c}\text { Second Order } \\
\text { Themes }\end{array}$} & \multirow{2}{*}{$\begin{array}{l}\text { Aggregate } \\
\text { Theoretical } \\
\text { Dimensions }\end{array}$} \\
\hline Interviews & Newspaper & $\begin{array}{l}\text { Archival } \\
\text { Websites }\end{array}$ & Reports & CPUC & $\begin{array}{l}\text { Resource } \\
\text { Plans }\end{array}$ & Video & & & \\
\hline 2 & 0 & 12 & 13 & 2 & 0 & 4 & $\begin{array}{l}\text { - Windsource price } \\
\text { increase } \\
\text { - Wind cannot compete on } \\
\text { price } \\
\text { - "Pay a little more" to } \\
\text { support wind energy }\end{array}$ & Elaboration & \multirow{3}{*}{$\begin{array}{l}\text { Logics } \\
\text { Relationship } \\
\text { (Field-level) }\end{array}$} \\
\hline 13 & 0 & 5 & 2 & 4 & 7 & 2 & $\begin{array}{l}\text { - } \quad \text { Wind when least-cost } \\
\text { - } \quad \text { Symbolic embrace of } \\
\text { ecologizing across field }\end{array}$ & Assimilation & \\
\hline 1 & 0 & 5 & 5 & 22 & 2 & 2 & $\begin{array}{l}\text { Integration of logics of } \\
\text { economizing and } \\
\text { ecologizing } \\
\text { Wind power is good for } \\
\text { business and good for the } \\
\text { environment }\end{array}$ & Hybridization & \\
\hline 25 & 0 & 0 & 0 & 5 & 0 & 0 & $\begin{array}{l}\text { Exercise of formal } \\
\text { authority } \\
\text { Power of actors through } \\
\text { new governance } \\
\text { arrangements }\end{array}$ & $\begin{array}{c}\text { Direct Influence on } \\
\text { Actors }\end{array}$ & \multirow{2}{*}{$\begin{array}{c}\text { Field } \\
\text { Centralization } \\
\text { (Field-level) }\end{array}$} \\
\hline 27 & 1 & 1 & 3 & 9 & 0 & 0 & $\begin{array}{l}\text { - New networks, alliances, } \\
\text { and legitimate actors } \\
\text { - Firm and SMO entry }\end{array}$ & $\begin{array}{l}\text { Stakeholder } \\
\text { Expansion }^{6}\end{array}$ & \\
\hline
\end{tabular}

\footnotetext{
${ }^{5}$ Role of direct influence on field power concentration

${ }^{6}$ Role of stakeholder expansion on field power concentration
} 
FIGURE 1

A Process of Logic Hybridization

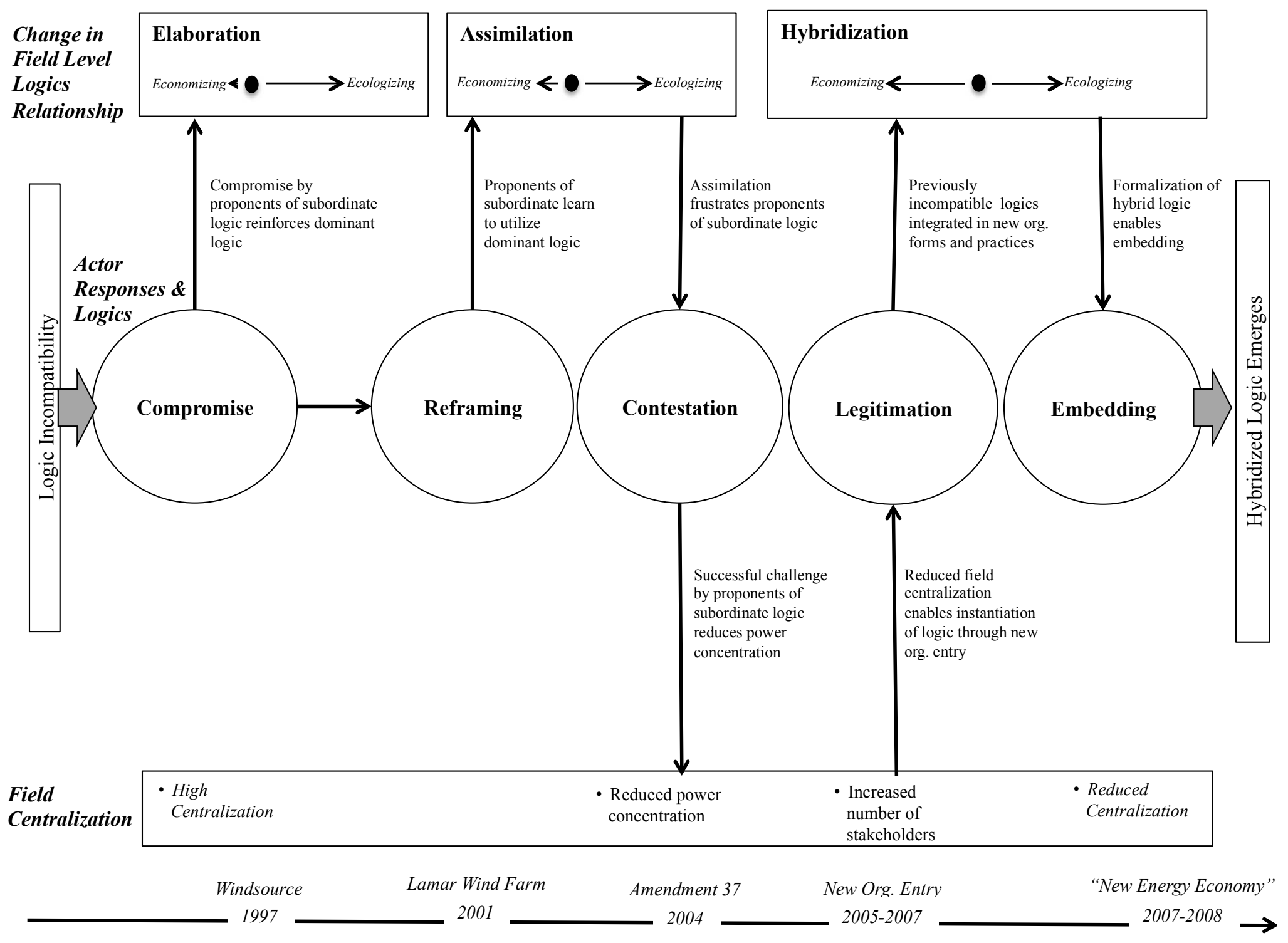


TABLE 3

Logic Ideal Types and Implications for the Wind Energy Field

\begin{tabular}{|c|c|c|c|c|}
\hline \multirow{2}{*}{ Logic } & \multirow{2}{*}{ Symbols/Goals } & \multicolumn{3}{|c|}{ Material Elements } \\
\hline & & Governance & $\begin{array}{r}\text { Practice } \\
\end{array}$ & Organizational Forms \\
\hline \multirow{3}{*}{ Economizing } & $\begin{array}{l}\text { - Seek the efficient use of } \\
\text { resources for material } \\
\text { improvement }\end{array}$ & $\begin{array}{l}\text { - Regulatory interference with free } \\
\text { markets regarding wind energy will } \\
\text { lead to inefficiency and human needs } \\
\text { not being met }\end{array}$ & $\begin{array}{l}\text { - Wind energy should only be adopted } \\
\text { when customers demand it and are } \\
\text { willing to pay and cost is acceptable }\end{array}$ & \multirow[t]{3}{*}{$\begin{array}{l}\text { - Investor owned utilities } \\
\text { - CPUC }\end{array}$} \\
\hline & $\begin{array}{l}\text { - Measure progress through } \\
\text { economic profits }\end{array}$ & $\begin{array}{l}\text { "...mandating the use of this expensive, } \\
\text { fluctuating energy source will not only }\end{array}$ & $\begin{array}{l}\text { "If we're going to have to compete for } \\
\text { customers, we better understand who } \\
\text { they are, what they want, what we }\end{array}$ & \\
\hline & $\begin{array}{l}\text { - Natural environment is a } \\
\text { resource to be utilized by } \\
\text { business and society }\end{array}$ & $\begin{array}{l}\text { increase electricity rates, it will wreak } \\
\text { havoc on the reliability of the electric } \\
\text { grid." (IREA, 2004) }\end{array}$ & $\begin{array}{l}\text { could offer them, how we could make } \\
\text { money off of them... Some alternative } \\
\text { ways of utilities making money. " } \\
\text { (Utility Executive) }\end{array}$ & \\
\hline \multirow{4}{*}{ Ecologizing } & $\begin{array}{l}\text { - Values focused on life } \\
\text { preservation through } \\
\text { community and linkage to }\end{array}$ & $\begin{array}{l}\text { - Regulatory intervention is required to } \\
\text { increase adoption of wind energy }\end{array}$ & $\begin{array}{l}\text { - Wind energy should be adopted to } \\
\text { reduce environmental degradation }\end{array}$ & \multirow[t]{4}{*}{ - Environmental SMOs } \\
\hline & nature & "We need a federal policy that & "...do something about climate change & \\
\hline & $\begin{array}{l}\text { - Measure progress through } \\
\text { conservation of nature and life }\end{array}$ & $\begin{array}{l}\text { recognizes the true costs of our energy } \\
\text { appetite - ... the impact on the global } \\
\text { environment and the lives of our sons } \\
\text { and daughters." (Brandemuehl, 2005) }\end{array}$ & $\begin{array}{l}\text { as well as all the other external costs } \\
\text { related to our heavy reliance on fossil } \\
\text { fuels... wind energy has been a big part } \\
\text { of that." (Environmental Activist) }\end{array}$ & \\
\hline & $\begin{array}{l}\text { - Natural environment is under } \\
\text { attack by negative } \\
\text { externalities of business }\end{array}$ & & & \\
\hline \multirow{6}{*}{ Hybridized } & $\begin{array}{l}\text { - Values simultaneous } \\
\text { achievement of economic } \\
\text { gains and environmental } \\
\text { welfare }\end{array}$ & $\begin{array}{l}\text { - Market players and governments can } \\
\text { work together to increase adoption of } \\
\text { wind energy }\end{array}$ & $\begin{array}{l}\text { - Wind energy provides opportunities } \\
\text { for entrepreneurship, jobs, and overall } \\
\text { improvement of the economy, while } \\
\text { enhancing environmental conditions }\end{array}$ & \multirow{6}{*}{$\begin{array}{l}\text { - Clean Energy SMOs } \\
\text { - Wind Energy Firms } \\
\text { - Investor owned utilities } \\
\text { - CPUC } \\
\text { - Government authorities } \\
\text { - Environmental SMOs }\end{array}$} \\
\hline & & "I am honored to be selected by Gov. & & \\
\hline & $\begin{array}{l}\text { - Measure progress through } \\
\text { long-term economic gains }\end{array}$ & $\begin{array}{l}\text { Ritter for this position," said Baker, } \\
\text { executive director of Environment }\end{array}$ & $\begin{array}{l}\text { "Because I think the public needs to } \\
\text { perceive (wind energy) as, good for the }\end{array}$ & \\
\hline & $\begin{array}{l}\text { through environmentally } \\
\text { responsible practices }\end{array}$ & $\begin{array}{l}\text { Colorado. "Colorado is at a point where } \\
\text { we can grow our economy, protect our } \\
\text { environment and provide an affordable }\end{array}$ & $\begin{array}{l}\text { environment but also good for the } \\
\text { economy. This is like the ultimate win- } \\
\text { win. It can't just be one or the other. }\end{array}$ & \\
\hline & $\begin{array}{l}\text { - Business practices can be part } \\
\text { of the solution to }\end{array}$ & $\begin{array}{l}\text { energy supply to the people and } \\
\text { businesses of Colorado. "(Office of the }\end{array}$ & $\begin{array}{l}\text { It's really got to be both. That's the } \\
\text { thing that gives it its pizzazz." (CPUC }\end{array}$ & \\
\hline & environmental problems & Governor of Colorado, 2008) & Commissioner) & \\
\hline
\end{tabular}


FIGURE 2

\section{Emergence of Wind Energy in Colorado ${ }^{7}$}

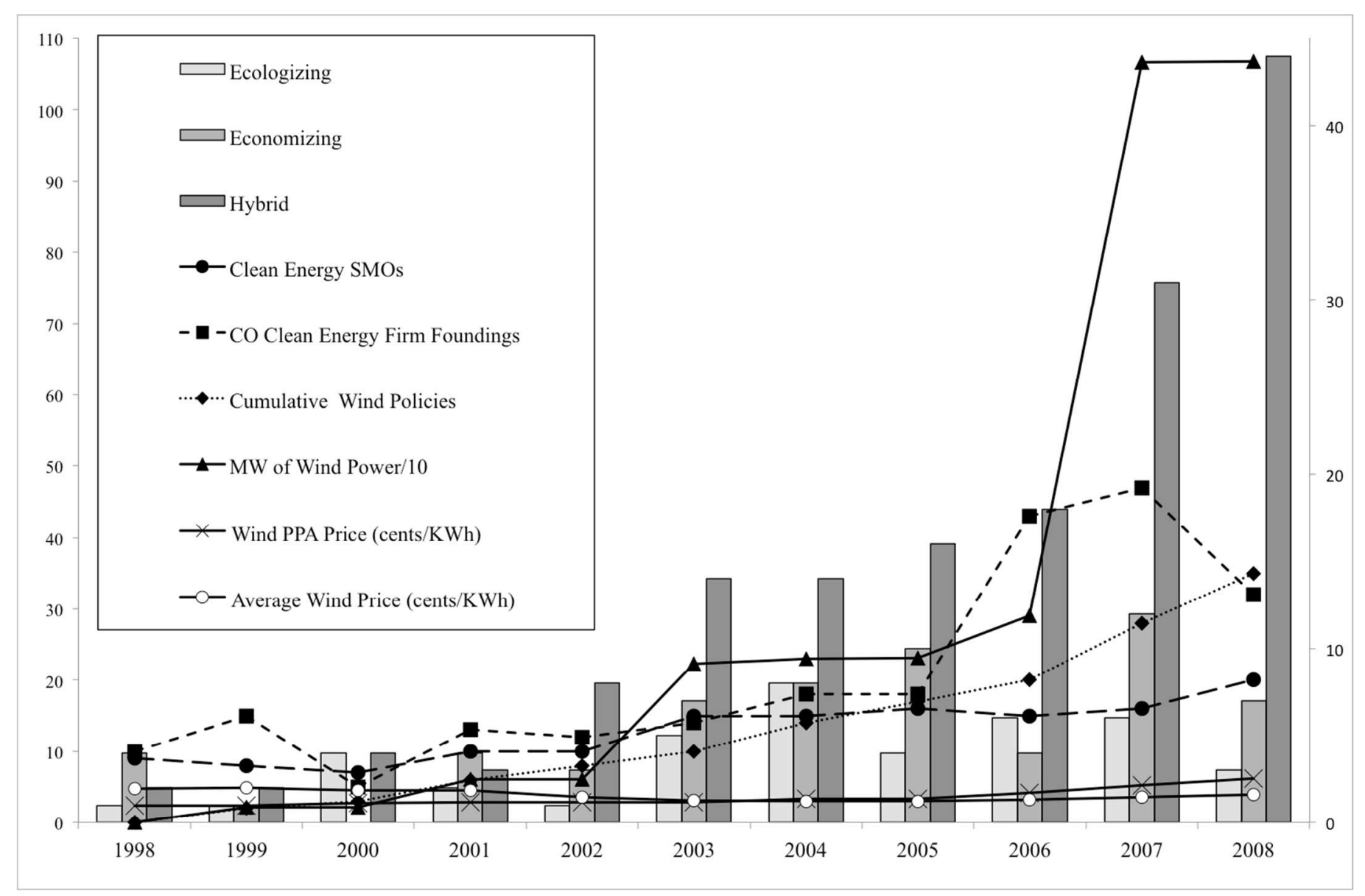

\footnotetext{
${ }^{7}$ The right axis is a count of codes for statements based in logics; all others are measured on the left axis. Data sources: Clean Energy SMOs: author compiled data from the National Center for Charitable Statistics. Wind Policies: author compiled data from the Database of State Incentives in Renewable Energy. MW of Wind and Firm Foundings: from CORE and Levenson (2009). National capacity average price by power purchase agreement (PPA) date and cumulative national capacity weighted average price from Wiser \& Bolinger (2012).
} 


\section{TABLE 4}

\section{Illustrative Evidence Supporting Interpretation of Organizational Responses and Logic of Actors ${ }^{8}$}

Theme Representative Quotations

Compromise "But we have something in common now...that odd coalition between environmentalists on the one hand and utility on the other... It was a combined effort to do something a little different and good." * (Environmental SMO Leader)

“... we agreed to emphasize the positive aspects of the product. And not everybody emphasize the negative parts about it." * (Utility Executive)

"The best outcome for advocates would have been regulatory mandates for renewable energy. Failing that, partnering with the utilities in their green pricing programs enhanced the regulatory outcome in the most recent integrated resource planning process and led to further renewable energy commitments." ** (Mayer et al., 1999)

"LAW Fund (WRA) and PSCo (Xcel) learned how to work together as a team, and the partnership started to run more smoothly. This involved open-mindedness and a willingness to respect different organizational goals and beliefs protecting the environment for the LAW Fund versus making a profit for PSCo.” ** (Mayer et al., 1999)

Reframing "To estimate dollar values of the avoided capacity savings, the LAW Fund (WRA) used the same $\$ 7 / \mathrm{kW} / \mathrm{month}$ capacity cost ...that Xcel had used in its portfolio evaluation process. The LAW Fund's analysis concluded that the wind bid would be a cost-effective addition..."** (Lehr, Nielsen, Andrews, \& Milligan, 2001)

"Advocates for alternative energies no longer make their arguments for wind on clean-air claims alone. They say the tripling of natural gas costs in the past year and widespread agreement that gas demand will outstrip supply in coming years makes wind a clear winner in a cold, hard price comparison." *** $(1 / 7 / 2001)$

"As we stripped away the fabricated assumptions that the utilities made to come up with that addition to the bid price... we found out that the real cost of the additional variability added by the wind plant were in the \$3- to \$5-million range, making the wind bid the lowest-cost resource that the utility had in the bid stack." * (Environmental SMO Attorney)

\footnotetext{
${ }^{8}$ A single asterisk denotes evidence from interview data followed by the speaker's role(s) in wind energy in Colorado; a double asterisk denotes evidence from archival data followed by the author and year of publication; a triple asterisk denotes evidence from Denver Post newspaper articles denoted with author and year of publication.
} 
TABLE 4

Illustrative Evidence Supporting Interpretation of Organizational Responses and Logic of Actors (cont.)

Theme Representative Quotations

Reframing (cont.)

Contestation

“... it was that experience, then, that led us to write some legislation that was considered three subsequent sessions of the legislature where we drafted and some legislators proposed a renewable energy standard for the state, because we had had this 10 -year-long litigation experience, frustration experience, with the low-cost resource being rejected. And it was time that the policymakers, who set up the monopoly structure for electric utilities said that it would be required that they buy a minimum amount of renewable energy since it had proven itself to be low cost, and they had proven themselves to be unwilling to buy it voluntarily." * (Environmental SMO Leader)

"We told them, 'Look, we don't want this just to be a bake sale where only $1 \%$ of the altruistic, more conscientious members of your customer base decide to give you more money to do the right thing. Why don't we just tap everybody?' And nothing really happened until we made it the law of the land in Colorado through the Amendment 37 in 2004 that there was no ifs, ands, and buts about it, and this is not a bake sale. This is the real thing. You have to have $10 \%$ of your power coming from renewable energy by the year 2015.” * (Environmental SMO Leader)

“And we are especially careful to ensure that our customers don't bear the burden of a certain class of expensive renewable technologies. For example, there will be an initiative on the November ballot in Colorado for a renewable energy mandate. It would require the state's largest energy providers to get 10 percent of their electricity from renewable sources by $2015 \ldots$... But we're concerned about the potential price impact that this initiative could have on our customers." ** (Xcel Energy, 2004)

"While wind advocates claim that wind is competitive with conventional generation, they fail to reveal its true costs. While the wind does blow for free, the initial cost of wind farms is much higher than other forms of generation. The cost per kilowatt of electricity is about $\$ 4,000$ - triple the cost of a coal-fired plant.” ** (IREA, 2004) 
Embedding “...the unforeseen political ramifications of that success (Amendment 37) was having people running for office as senators or representatives or even the governor who... added, "And I will, if you elect me, I will ensure that we continue down this path of renewable energy."...We who campaigned for Amendment 37, we never knew that we were also setting up a political dynamic. We pretty much thought it was literally going to be resulting in $10 \%$ by 2015 , and that would be the end of our efforts. But we pretty quickly realized that the political environment was paying attention. So that's number two, is the elections in 2006 by a crop of legislators who could talk in some detail about how renewable energy is going to advance a new energy economy in Colorado.” * (Environmental SMO Leader/PUC Commissioner)

"Two years after voters passed the original RES, newly-elected Governor Bill Ritter championed legislation, passed by the general assembly, which doubled the RES requirement to $20 \%$ by 2020 , and expanded its application to all Colorado's rural electric cooperatives. The legislation increasing the RES was supported by the state's utilities."** (CPUC, 2007)

“The Commission's decisions in Phase I and II must also consider new issues, including possible federal carbon regulations, the Governor's Climate Change Action Plan goal of CO2 reduction goal of 20 percent by 2020, the 2 percent renewable rate cost cap, DSM potential, new renewable resources such as concentrating solar power (CSP) which may include energy storage, as well as many other electricity supply and demand variables.”** (CPUC, 2008a) 


\section{TABLE 5}

\section{Illustrative Evidence Supporting Interpretation of Change in Field-level Logics Relationship}

\begin{tabular}{|c|c|}
\hline Theme & Representative Quotations \\
\hline \multirow[t]{2}{*}{ Elaboration } & $\begin{array}{l}\text { "Wind-generation proponent Rick Gilliam of Boulder-based Western Resource Advocates takes issue with Xcel's position. } \\
\text { "The goal is not to have people pay a premium," he said. 'They signed up to use a renewable resource, and if that cost is } \\
\text { cheaper, so much the better." *** }(5 / 25 / 2005)\end{array}$ \\
\hline & $\begin{array}{l}\text { "'This is a premium price program, and customers that elect to join the Windsource program have decided to pay more to } \\
\text { build up wind power in the state," Xcel spokeswoman Ethnie Groves said. "This was never designed to be competitive with } \\
\text { traditional generation." *** }(6 / 14 / 2006)\end{array}$ \\
\hline \multirow[t]{3}{*}{ Assimilation } & $\begin{array}{l}\text { "It shows that wind is cost-effective. And it will open the door for other renewable-energy projects,' said Rudd Mayer of } \\
\text { Boulder's Land and Water Fund. " *** }(2 / 24 / 2001)\end{array}$ \\
\hline & $\begin{array}{l}\text { “... the PUC concluded that Xcel's preferred plan... was a reasonable plan for meeting the company's supply needs at the } \\
\text { least cost to consumers. But the PUC also ruled that the proposed wind project was a cost-effective bid that should be } \\
\text { included in the company's portfolio.”** (CPUC, 2001b) }\end{array}$ \\
\hline & $\begin{array}{l}\text { It was one of the first times that I know about where the costs of wind were actually litigated on a public record. And the } \\
\text { costs were found to be lower than the cost of competing resources; it was an economic decision by economic regulators.* } \\
\text { (Environmental SMO Leader) }\end{array}$ \\
\hline \multirow[t]{3}{*}{ Hybridization } & $\begin{array}{l}\text { "Therefore, we find that the following externalities shall be factored qualitatively into the Phase II decision: a) b) c) } \\
\text { Economic development (rural impact; job development; tax base; etc.); Resource diversification; and Environmental benefits } \\
\text { associated with emissions reductions and other environmental impacts beyond permit compliance." ** (CPUC, 2008a) }\end{array}$ \\
\hline & $\begin{array}{l}\text { "The PUC chairman will also talk about how Colorado's renewable energy standard has served to jump-start the state's } \\
\text { renewable energy industry, creating an estimated 22,000 direct "green-collar jobs," and how it has helped the state make } \\
\text { progress towards the goals of Gov. Ritter's Climate Action Change Plan to reduce greenhouse gas emissions." ** (CPUC, } \\
2007 \text { ) }\end{array}$ \\
\hline & $\begin{array}{l}\text { "Over the past several years, renewable energy has become the great unifier in Colorado politics, an issue so popular and so } \\
\text { multifaceted that just about every lawmaker can find something there to like. Environmentalists love its eco-friendliness. ... } \\
\text { Economy wonks love the promise of new jobs that come with the burgeoning industry. Support in some form or another for } \\
\text { renewable energy bridges party and geographic lines." *** (3/31/2008) }\end{array}$ \\
\hline
\end{tabular}




\section{Illustrative Evidence Supporting Interpretation of Changes in Field Centralization}

\section{Theme}

\section{Representative Quotations}

Reduced

$\begin{array}{ll}\text { Power } & \text { oppose it ...basically kind of put the imprimatur of an election on this decision to get a fairly modest amount of renewables } \\ \text { Concentration } & \text { from wind...that basically kind of enshrined wind as something that not only did technically it make a lot of sense but also the }\end{array}$

"What Amendment 37 did was because the voters actually voted for it. And the utilities opposed it, and they spent money to people actually voted on it." * (Environmental SMO Leader/PUC Commissioner)

“This election has placed the public back in public utilities,' said Manolo Gonzalez-Estay, co-director of the Amendment 37 campaign." *** (11/4/2004)

Increased "If there is a wind energy company that's going to move from Austin, Texas to Denver, Colorado, and they're bringing 20

Number of

Stakeholders people with them, you can rest assured that they just have to give us a call here at the Governor's Energy Office and we'll ensure that the governor's going to greet them with the media attention and press releases that are congratulating that Austin company from deciding to move to Colorado... that sounds kind of superficial. But when you talk about a company like Vestas that is bringing in 2,500 jobs and has the world's largest wind factories here in Colorado, and you ask them straight up, 'Why did you move to Denver, Colorado?' Well, the answer is because 'We felt like we were at home here, because we recognize that the leadership and the government and the policies and the people want us to be here. And that's the kind of place where we want to do business.'” * (Governor's Energy Office Official)

"Members of the public who attend a town meeting on energy issues in Windsor will be able to trade their bright ideas for energy-efficient light bulbs. The Colorado Public Utilities Commission (PUC) and the Colorado Office of Consumer Counsel (OCC) of the Colorado Department of Regulatory Agencies are hosting the meeting... The first 50 people who show up at the town meeting will receive a free compact fluorescent light bulb. The PUC and OCC have teamed up with Lowe's hardware stores and the Governor's Energy Office to sponsor the light bulb giveaway. Along with the rest of the nation and the world, Colorado is facing unprecedented change in terms of selection of electric generation resources, transmission, and clean energy goals." ** (CPUC, 2008b) 
APPENDIX A

Baseline Interview Protocol

Interview Protocol v.3

\section{Q.1 Background}

Can you tell me about your background and how you came to be involved in wind energy?

\section{Q.1a Early Involvement}

How were you involved in the early days of wind energy in Colorado?

\section{Q.1b Current Involvement}

Could you describe your current involvement with wind energy?

\section{Q.1c CO Wind Story}

How would you tell the story of wind energy in Colorado?

\section{Q.1d Key Events}

What were the key events in the history of wind energy in Colorado?

\section{Q.1e NGOs}

To what extent are NGOs responsible for the adoption of wind energy in Colorado?

\section{Q.1f Businesses}

To what extent are business and entrepreneurs responsible for the adoption of wind energy in Colorado?

\section{Q.1g Government}

To what extent is the government/policy responsible for the adoption of wind energy in Colorado?

\section{Q.1h Utilities}

To what extent are utilities responsible for the adoption of wind energy in Colorado?

\section{Q.1i Technology}

To what extent is technological change responsible for the adoption of wind energy in Colorado?

\section{Q.1j Field Change over Time}

How would you say the field of wind energy in Colorado has changed since your involvement began?

\section{Q.1k Organizational Change over Time}

How has your organization's view of wind energy in Colorado changed since your involvement began, if it has?

\section{Q.1I Other issues}

Are there any other issues regarding wind energy in Colorado that you feel we should have discussed?

\section{Q.1I Snowball}

Whom else would you suggest we interview? 


\section{Biographical Sketches}

Jeffrey G. York (jeffrey.york@colorado.edu) is an assistant professor of management and entrepreneurship and the Shane Faculty Scholar at the University of Colorado Boulder. His research interests include environmental entrepreneurship, collective action, identity theory, and the evolution and emergence of new, environmentally relevant sectors. He received his Ph.D. from the Darden School of Business at the University of Virginia.

Timothy J. Hargrave is a lecturer at the Albers School of Business, Seattle University, and the Beedie School of Business, Simon Fraser University. He received his Ph.D. from the University of Minnesota's Carlson School of Management. His research interests include institutional change, sustainability, and business ethics.

Desirée F. Pacheco is an assistant professor of management at Portland State University and the Hanna Andersson Scholar in Management and Sustainability. She received her Ph.D. from the Leeds School of Business at the University of Colorado. Her research interests are at the interface of institutions, entrepreneurial innovation, and firm strategy. She applies these areas of research to the study of sustainable business. 